\title{
International Transmission of Financial Shocks in an Estimated DSGE model*
}

\author{
Sami Alpanda ${ }^{a}$, Uluc Aysun ${ }^{b^{* *}}$ \\ a Bank of Canada, Ottawa, Ontario, Canada \\ b University of Central Florida,Orlando, FL32816
}

October, 2012

\begin{abstract}
This paper investigates the transmission mechanism of financial shocks across large economies. To quantify these effects, we construct and estimate a two-region open economy DSGE model with nominal and real rigidities. We model the financial side of the economies using the financial accelerator mechanism of Bernanke et al. (1999). We find that the baseline model fails to generate the high degree of macroeconomic correlation between the U.S. and Euro Area economies. Allowing for an ad hoc, cross-regional correlation in financial shocks considerably improves the model's ability to replicate the spill-over effects of U.S. financial shocks. We then extend the baseline model by including global banking and generate an endogenous, crossregional correlation of cost of capital. Simulations demonstrate a larger Euro Area response to U.S. shocks and highlight the importance of including frictions in international financial contracts, and not only in domestic financial contracts, for more accurately capturing the international transmission of domestic shocks.
\end{abstract}

JEL Classifications: E32, E44, F33, F44.

Keywords: DSGE, financial accelerator, international business cycles, global banks.

\footnotetext{
* We thank the participants of the 2010 Midwest Macroeconomics Meetings for helpful comments and discussions. All errors are ours. The views expressed in this paper are solely those of the authors, and no responsibility for them should be attributed to the Bank of Canada.

**Corresponding author: Department of Economics, University of Central Florida, College of Business Administration 4000 Central Florida Blvd., Orlando, Florida 32816-1991, Email: uaysun@bus.ucf.edu ph. +1 530 574 3951, fax: +1 4078233269 .
} 


\section{Introduction}

The recent financial crisis that originated in the U.S. has clearly demonstrated that frictions caused by asymmetric information in financial markets can have a significant impact on spending decisions and the level of economic activity even in mature markets. One important characteristic of the current crisis was that the contractionary effects of the financial shock were not confined to the U.S., and countries with exposure to U.S. asset markets were negatively and significantly affected. Although the decline in economic activity in the U.S. was a factor in the cross-country spill-over effects through trade, the immediate response of foreign economies were most likely prompted by their exposure to distressed U.S. assets and U.S. funding markets. Furthermore, there is evidence (see Figure 1) that the correlation between U.S. and Euro Area output, costs of capital and stock price indices are quite high; any realistic large open economy model would therefore be expected to replicate and account for these high levels of correlations.

In this paper, we estimate a two-region, open economy, dynamic stochastic general equilibrium (DSGE) model to quantify the effects of U.S. financial shocks on the Euro Area economies. In this model we include the financial accelerator mechanism described by studies such as Bernanke et al. (1999) and Carlstrom and Fuerst (1997) to improve the model's ability to capture the amplification and propagation effects of financial frictions. We find that the baseline model, in which the two regions are linked only through international trade and bond markets, fails to generate the high degree of macroeconomic correlation between the U.S. and Euro Area economies. Although turning the financial accelerator mechanism on and off (or including and excluding financial frictions) reveals significant effects of this mechanism on the economies in which shocks originate, the international spill-over effects of the mechanism are very small. We find much larger international spill-over effects and a higher degree of cross-regional 
macroeconomic correlation when we allow for financial shocks to be correlated across the two regions. Specifically, by estimating the correlation between interest rate (policy rate), cost of capital and net worth shocks and using these correlations in our post-estimation simulations, we find a much larger response of Euro Area variables to U.S. financial shocks. When we estimate shock correlations, business cycle properties of the model are also more similar to those observed in the data, and historical decompositions illustrate that U.S. shocks, financial and real, explain a larger share of Euro Area output volatility.

Despite these improvements, allowing for an ad hoc correlation between the financial shocks of the two regions does not help in making sound predictions for the spill-over effects of financial shocks. Specifically, predictions based on the estimated values of the correlation coefficients of financial shocks would be inaccurate when these shocks do not behave the way do on average and/or if they are endogenously determined by other variables in the model. Therefore, in the second half of the paper, we extend the baseline model with global banking to investigate one reason why financial shocks could be correlated across regions. Using this model, we generate an endogenous correlation between financial shocks, and compare the results with those obtained from the model estimated using ad hoc correlations. In our extension, we focus on the shocks to cost of capital (i.e. credit spreads), and more rigorously model the supply side of capital by allowing banking activity to be global, and by reasonably restricting banks to pay a premium in raising loanable funds over the risk-free rate. This premium is caused by an idiosyncratic net worth shock that banks face and, similar to the premium paid by the entrepreneur in the financial accelerator framework, it is an increasing function of banks' financial leverage. The optimality conditions from this model indicate that banks not only consider the borrowers' leverage but also their own leverage when choosing lending rates. Therefore, if there is an increase (decrease) in the demand for loans in one region this increases 
(decreases) the risk premium in both regions since banks' leverage is now higher (lower). Shocks to banks' net worth and/or shocks that affect banks' net worth have a similar, symmetric effect on risk premiums in both regions. The impulse responses demonstrate a large response of Euro Area output to U.S. shocks, and output correlation across regions is more consistent with the data compared to the baseline model.

The results more generally suggest that models in which financial frictions (or bankruptcy costs in the financial accelerator mechanism) only apply to domestic contracts are not sufficient for generating a large foreign response to domestic shocks. To obtain this large response, financial frictions should also be incorporated into international financial contracts. In this paper, we use global banking as a means to applying financial frictions to international contracts. Here, the assumption that we make, i.e., banking activity is global in scale, is not an unrealistic one. Specifically, recent studies such as Bruno and Shin (2012) and Cetorelli and Goldberg (2012) illustrate the rapid pace of bank globalization and data from the Bank of International Settlements reporting banks indicate that the growth in external assets and liabilities of global banks has outpaced the growth in world GDP over the past 15 years. In our model we also find that global banks are an important source of international spill-over effects. This is consistent with the usual finding that international banking, conducted largely through internal capital markets, has a significant effect on local business cycles (e.g. Alpanda and Aysun, 2012; Buch, 2000; Dahl and Shrieves, 1999; De Haas and Van Lelyveld, 2006, 2010; Goldberg, 2002; Jeanneau and Micu, 2002; Martinez Peria et al., 2002; Morgan and Strahan, 2004).

In our model, by assuming that banks pay a premium (positively related to their leverage) in raising loanable funds, we are effectively broadening the scope of how financial shocks can affect the real economy (domestically and internationally). Specifically, in the usual financial 
accelerator framework financial shocks are transmitted to the real economy only through borrower balance sheets (through the demand side) and banks play a passive role. By contrast, recent studies (following the Great Recession) identify bank balance sheets as an important determinant of how financial shocks propagate (e.g. Gertler and Karadi, 2011; Meh and Moran, 2010; Davis, 2011; Kollmann et al., 2011, 2012). By incorporating bank balance sheets in our model, we therefore allow for the transmission of shocks through both demand side variables such as asset price and entrepreneurs' net worth and the supply side variables such as banks' net worth and leverage, and more completely describe how credit market disturbances can affect the real economy. Our findings indicate that banks' borrowing constraints play an important role in amplifying the Euro Area responses to U.S. interest rate shocks. This implies that although the lending channel of monetary transmission (how the central bank affects the real economy through its impact on banks' borrowing costs) may be declining in the U.S. (for evidence see, Ashcraft, 2006; Kashyap and Stein, 2000; Loutskina and Strahan, 2009; Morgan et al., 2004), it may still be operating effectively at the international level.

At this point we should mention that global banking is not the only financial link between the U.S. and the Euro Area economies, and including other aspects of international financial markets such as the presence of cross-regional equity holdings and the exposure of banks to assets other than loans would make the model more realistic and it would allow one to determine how these aspects affect international transmission of shocks. The main reason we do not enhance our model to incorporate other financial linkages is that the dimension of the model is quite large and convergence in the estimation process is difficult (the baseline model includes 112 variables and 81 parameters). Although it would be easier to extend the model by using a calibration methodology to solve it, we choose to estimate the model for two main reasons. First, our model includes non-standard parameters such as those governing the sensitivities to borrower 
and bank balance sheets and the literature, so far, does not agree on what values to use and how to calibrate models that have these features. Second and more importantly, in accurately quantifying the impact of U.S. shocks on the Euro Area economy, it is critical to estimate the size and the persistence of U.S. shocks and how they are correlated with Euro Area shocks. The estimation of the shock processes is, therefore, a more informative strategy compared to arbitrarily choosing shock parameters values. Furthermore, by including various nominal and real rigidities in the model as in Christiano et al. (2005) and Smets and Wouters (2007), we enhance our model's ability to match the common characteristics of the usual VAR impulse responses. By estimating a two-region model, we complement the literature that mostly focuses on a single economy given the difficulties in estimating a model with these features.

Our paper is also complements the international business cycles literature that uses two country models to replicate international business cycle stylized facts. Following the low output correlation (and higher consumption correlation) produced by the Backus et al. (1992) two country framework (also known as the quantity anomaly), researchers have included trade frictions and differences in size/location to decrease the risk sharing between countries and increase output correlation (e.g. Baxter and Crucini, 1995; Kollmann, 1995; Zimmermann, 1997). More recent studies have included frictions in financial markets to match the stylized facts, but they are small in number (c.f. Davis, 2011; Devereux and Yetman, 2010; Gertler et al., 2007; Faia, 2007; Kollmann, 2012; Yao, 2012). ${ }^{1}$

\footnotetext{
${ }^{1}$ Our paper is related to Kollmann (2012) who also explores the role of global banking in an estimated international real business cycle model. While external finance premium for entrepreneurs in this paper arises due to the frictions in the supply side of the credit market (due to costs of loan origination and deviations from the regulatory bank capital measures), in our paper financial frictions in both the demand and the supply side generate the external finance premium. Our model also differs from the aforementioned paper by featuring nominal rigidities as well as financial and real frictions. Our paper is also related to Davis (2011) which also features a two-economy model with financial frictions in the demand and supply or loans. We differ from this paper by featuring global banking,
} 
The rest of the paper is organized as follows: Section 2 presents the baseline model. Section 3 describes the data and the Bayesian estimation strategy. Section 4 discusses the results. Section 5 describes the model with cross-regional banking and presents the results. Section 6 concludes.

\section{The baseline model}

\subsection{General Overview}

The baseline model is a two-country open economy version of the standard New Keynesian DSGE model (Smets and Wouters, 2007, and Christiano et al, 2005) appended with a financial accelerator mechanism (Bernanke et al., 1999, Gertler et al., 2007, and Gilchrist et al., 2009). Monopolistically competitive retail firms are price-setters in the goods market, and households are wage-setters in the labor market. Nominal rigidities are introduced through staggered price and wage-setting as in Calvo (1983) and through indexation of prices and wages to past inflation. The model features intermediaries in each country which import consumption and investment goods from abroad and sell them domestically in the local currency; staggered price-setting for

these intermediaries result in incomplete exchange rate pass-through (Gertler et al., 2007). Each country also has financial intermediaries which accept deposits from households and lend to domestic entrepreneurs in order to finance their investment. They charge a risk-premium on their lending based on the financial leverage of the entrepreneurs; these assumptions produce the financial accelerator mechanism described by Bernanke et al. (1999).

In what follows, we briefly describe the equations that characterize the equilibrium of the model after all variables are log-linearized around their steady-state. Further details of the micro-

estimating the parameters of the model rather than using a calibration strategy and by examining the role that financial frictions play in the international transmission of financial shocks. 
foundations of the model can be found in Smets and Wouters (2007), Gertler et al. (2007), Gilchrist et al. (2009), Bernanke et al. (1999) and Alpanda (2012).

\subsection{Log-linearized Equilibrium Conditions}

Consumption demand is characterized by a partially forward-looking IS curve which is obtained from the first-order-condition of the households' maximization problem with respect to consumption and the Euler condition:

$c_{t}=\frac{\lambda / \gamma}{1+\lambda / \gamma} c_{t-1}+\frac{1}{1+\lambda / \gamma} E_{t} c_{t+1}+\frac{(1-\lambda / \gamma)}{\sigma(1+\lambda / \gamma)}\left[(\sigma-1) \xi\left(l_{t}-E_{t} l_{t+1}\right)-\left(r_{t}-E_{t} \pi_{t+1}\right)\right]+\varepsilon_{c, t}$,

where $t$ indexes time, $c_{t}$ is consumption, $l_{t}$ is labor, $r_{t}$ is the nominal interest rate set by the central bank, and $\pi_{t}$ is the CPI inflation rate. $\lambda$ is the (external) habit parameter in the household utility function, $\gamma$ is the steady-state per-capita growth rate of the economy, $\sigma$ is the inverse of the intertemporal elasticity of substitution, and $\xi$ is a level parameter in the households' utility function which, without loss of generality, will be calibrated to ensure the steady-state value of labor is equal to $1 . \varepsilon_{c, t}$ is a consumption demand shock which follows an $\operatorname{AR}(1)$ process characterized by $\varepsilon_{c, t}=\rho_{c} \varepsilon_{c, t-1}+\eta_{c, t}$ where $\rho_{c}$ is the persistence parameter, and $\eta_{c, t}$ is the shock innovation which is distributed i.i.d. normal with mean 0 and standard deviation $\sigma_{c}{ }^{2}$ The IS curve states that current consumption is inversely related to the ex-ante real interest rate, positively related to demand shocks, and is influenced by past and expected future consumption and labor services.

\footnotetext{
${ }^{2}$ For brevity, we omit the equations for the rest of the shocks that follow $\operatorname{AR}(1)$ processes. We will use $\rho$ for the persistence parameters, and $\sigma$ for the standard deviation of the innovations of these shocks with appropriate subscripts.
} 
Consumption is a composite of the home-produced consumption good, $c_{h, t}$, and imported consumption good, $c_{f, t}$, as

$c_{t}=\gamma_{c} c_{h, t}+\left(1-\gamma_{c}\right) c_{f, t}$,

where $\gamma_{c}$ is the share of domestic goods in the consumption aggregator function. In equilibrium, the consumption of domestic and foreign goods are related to each other as follows:

$c_{h, t}-c_{f, t}=\lambda_{c} s_{t}$,

where $\lambda_{c}$ is the intratemporal elasticity of substitution between home and foreign goods in the consumption aggregator, and $s_{t}=p_{f, t}-p_{h, t}$ is the terms-of-trade where $p_{f, t}$ and $p_{h, t}$ are the domestic prices associated with the foreign-produced and home-produced goods respectively.

Investment demand is derived from the first-order conditions of capital-producers and it is given by

$i_{t}=\frac{1}{1+\widetilde{\beta}} i_{t-1}+\frac{\tilde{\beta}}{1+\widetilde{\beta}} E_{t} i_{t+1}+\frac{1}{1+\widetilde{\beta} \varphi}\left(q_{t}-p_{t}^{i}\right)+\varepsilon_{i, t}$

where $i_{t}$ is investment, $q_{t}$ is the real price of capital relative to the consumption good, and $\varepsilon_{i, t}$ is an investment-specific technological change shock which follows an $\operatorname{AR}(1)$ process. $\tilde{\beta}$ is the adjusted time-discount factor, and is equal to $\beta \eta \gamma^{1-\sigma}$ where $\beta$ is the simple time-discount factor of households, and $\eta$ is the population growth rate. $\varphi$ is an investment adjustment cost parameter, and regulates the elasticity of investment demand with respect to the price of capital and $p_{t}^{i}$ is the relative price of investment goods. 
Similar to the consumption good, the investment good is also a composite of domestically-produced investment goods, $i_{h, t}$, and imported consumption goods, $i_{f, t}$,

$i_{t}=\gamma_{i} i_{h, t}+\left(1-\gamma_{i}\right) i_{f, t}$,

where $\gamma_{i}$ is the share of domestic goods in the investment aggregator function. In equilibrium, the investment of domestic and foreign goods are related to each other as follows:

$i_{h, t}-i_{f, t}=\lambda_{i} s_{t}$,

where $\lambda_{i}$ is the intratemporal elasticity of substitution between home and foreign goods in the investment aggregator.

Domestic output is characterized by the following production function:

$y_{t}=\phi_{p}\left[\varepsilon_{a, t}+\alpha\left(z_{t}+k_{t-1}\right)+(1-\alpha) l_{t}\right]$,

where $y_{t}$ is output, $\varepsilon_{a, t}$ is a productivity shock following an $\mathrm{AR}(1)$ process, $z_{t}$ is the utilization rate of capital, and $k_{t}$ is the capital stock. The parameter $\alpha$ regulates the share of capital services in production, and $\phi_{p}$ is the gross mark-up of home-good prices over marginal cost at the steady-state, which also equals one plus the steady-state share of fixed costs in production.

In equilibrium, the marginal product of capital, $m p k_{t}$, is related to the capital-labor ratio and real wages, $w_{t}$, as

$m p k_{t}=-\left(z_{t}+k_{t-1}-l_{t}\right)+w_{t}$,

and capital utilization is related to the marginal product of capital as 
$z_{t}=\left(\frac{1-\psi}{\psi}\right) m p k_{t}$

where $\psi$ is an elasticity parameter. The law of motion of capital is given by

$k_{t}=\frac{1-\delta}{\eta \gamma} k_{t-1}+\left(1-\frac{1-\delta}{\eta \gamma}\right)\left[i_{t}+(1+\tilde{\beta}) \varphi \varepsilon_{i, t}\right]$

where $\delta$ is the depreciation rate of capital. The returns to capital (or the realized borrowing cost), $r_{k, t}$, is defined over capital gains and marginal product of capital:

$r_{k, t}=\frac{(1-\delta) \tilde{\beta}}{\eta \gamma} q_{t}+\left(1-\frac{(1-\delta) \tilde{\beta}}{\eta \gamma}\right) m p k_{t}-q_{t-1}$

The required return demanded by financial intermediaries include an external finance premium which is negatively related to the net worth of entrepreneurs, $n_{t}$ and positively related to the entrepreneurs' demand for capital. ${ }^{3}$

$$
E_{t} r_{k, t+1}=r_{t}-E_{t} \pi_{t+1}+\chi\left(q_{t}+k_{t}-n_{t}\right)+\varepsilon_{k, t},
$$

where $\chi$ is the elasticity of the risk-premium with respect to leverage, and $\varepsilon_{k, t}$ is an exogenous risk-premium shock following an $\mathrm{AR}(1)$ process. The net worth of entrepreneurs evolve according to

$n_{t}=\gamma_{e} n_{t-1}+E_{t-1} r_{k, t}+\frac{K}{N}\left(r_{k, t}-E_{t-1} r_{k, t}\right)+\varepsilon_{n, t}$,

\footnotetext{
${ }^{3}$ Here we follow Bernanke et al. (1999) and assume that entrepreneurs purchase their capital stock in each period. This assumption ensures that the financial contract applies to the entrepreneurs' total assets and not just their marginal investment in each period.
} 
where $\gamma_{e}$ is the survival probability of entrepreneurs, $K / N$ is their steady-state capital to networth ratio, and $\varepsilon_{n, t}$ is an $\mathrm{AR}(1)$ shock to net worth.

The home-goods producers' problem yields a partially forward-looking New Keynesian Phillips curve for home-goods price inflation:

$$
\pi_{h, t}=\frac{i_{h}}{1+i_{h} \widetilde{\beta}} \pi_{h, t-1}+\frac{\tilde{\beta}}{1+i_{h} \widetilde{\beta}} \pi_{h, t+1}-\frac{\left(1-\xi_{h}\right)\left(1-\xi_{h} \tilde{\beta}\right)}{3.5 \xi_{h}\left(1+i_{h} \tilde{\beta}\right)}\left[\varepsilon_{a, t}+\alpha\left(z_{t}+k_{t-1}-l_{t}\right)-w_{t}\right]+\varepsilon_{h, t},
$$

where $\pi_{h, t}=p_{h, t}-p_{h, t-1}$ is the inflation rate associated with home-good prices, and $\varepsilon_{h, t}$ is a costpush shock which follows an ARMA(1,1) process given by $\varepsilon_{h, t}=\rho_{h} \varepsilon_{h, t-1}+\eta_{h, t}-\mu_{h} \eta_{h, t-1}$. The parameter $t_{h}$ determines the degree to which prices are indexed to past domestic price inflation, and $\xi_{h}$ is the probability that firms cannot adjust their prices in any given period. ${ }^{4}$ The above Phillips curve ties current home-good inflation rate to past and expected future inflation as well as the marginal cost (i.e. the difference between the real wage and the marginal product of labor) of firms.

Similarly, foreign-goods price inflation is described by a forward-looking Phillips curve:

$\pi_{f, t}=\frac{\iota_{f}}{1+l_{f} \widetilde{\beta}} \pi_{f, t-1}+\frac{\tilde{\beta}}{1+l_{f} \widetilde{\beta}} \pi_{f, t+1}-\frac{\left(1-\xi_{f}\right)\left(1-\xi_{f} \tilde{\beta}\right)}{3.5 \xi_{f}\left(1+l_{f} \tilde{\beta}\right)} \Lambda_{t}+\varepsilon_{f, t}$,

where $\pi_{f, t}=p_{f, t}-p_{f, t-1}$ is the inflation rate associated with foreign-good prices, and $\varepsilon_{f, t}$ is a cost-push shock which follows an ARMA(1,1) process given by $\varepsilon_{f, t}=\rho_{f} \varepsilon_{f, t-1}+\eta_{f, t}-\mu_{f} \eta_{f, t-1}$. The parameter $l_{f}$ determines the degree to which prices are indexed to past foreign-good price

\footnotetext{
${ }^{4}$ The 3.5 term in the denominator comes from the Kimball aggregator function used by final goods producers at the calibrated values in Smets and Wouters (2007). There is a similar term in the New-Keynesian Phillips curve expressions for imported price and wage inflation in equations 15 and 19.
} 
inflation, and $\xi_{f}$ is the probability that importer intermediary firms do not adjust their prices in any given period. $\Lambda_{t}$ is the deviation of imported-good prices from the law-of-one-price and is given by $p_{f, t}-\left(e_{t}+p_{h, t}^{*}\right)$, where $e_{t}$ is the nominal exchange rate (in units of home-currency per unit of foreign currency) and $p_{h, t}^{*}$ is the home-goods price of the foreign country (i.e. the price at which the importer intermediaries in the home country import the foreign good). ${ }^{\mathbf{5}}$

Overall consumer goods inflation and the relative price of investment goods in the home country are given by the following two equations:

$$
\begin{aligned}
& \pi_{t}=\left(1-\gamma_{c}\right) \pi_{h, t}+\gamma_{c} \pi_{f, t}, \\
& p_{t}^{i}=\left(1-\gamma_{i}\right) p_{h, t}+\gamma_{i} p_{f, t} .
\end{aligned}
$$

The relationship between nominal wage inflation, $\pi_{w, t}$, consumer price inflation and real wages can be expressed as

$$
\pi_{w, t}=w_{t}-w_{t-1}+\pi_{t}
$$

Staggered wage-setting by households yields the following wage inflation Phillips curve:

$$
\pi_{w, t}-l_{w} \pi_{t-1}=\tilde{\beta}\left(E_{t} \pi_{w, t+1}-l_{w} \pi_{t}\right)-\frac{\left(1-\xi_{w}\right)\left(1-\xi_{w} \tilde{\beta}\right)}{6 \xi_{w}}\left\{w_{t}-\left[\sigma_{l} l_{t}+\frac{1}{1-\lambda / \gamma}\left(c_{t}-\frac{\lambda}{\gamma} c_{t-1}\right)\right]\right\}+\varepsilon_{w, t},
$$

where $\varepsilon_{w, t}$ is a cost-push shock following an $\operatorname{ARMA}(1,1)$ process $\varepsilon_{w, t}=\rho_{w} \varepsilon_{w, t-1}+\eta_{w, t}-\mu_{w} \eta_{w, t-1}$. $\iota_{w}$ is the parameter determining the degree of inflation indexation of nominal wage inflation, $\sigma_{l}$ is the inverse of the elasticity of labor supply, and $\xi_{w}$ is the probability that households do not adjust their wages in any given period. The wage Phillips curve ties current wage inflation to the

\footnotetext{
${ }^{5}$ As a convention, we will designate the foreign economy variables and parameters with the same names as their counterparts in the home country, but with an asterisk $(*)$ superscript.
} 
difference between real wages and the marginal rate of substitution between consumption and leisure, as well as past and present price inflation, and expected future wages.

Monetary policy is conducted via a Taylor rule for the nominal interest rate:

$r_{t}=\rho r_{t-1}+(1-\rho)\left[r_{\pi} \pi_{t}+r_{y} y_{t}+r_{\Delta y}\left(y_{t}-y_{t-1}\right)\right]+\varepsilon_{r, t}$,

where $\rho$ is the interest-rate smoothing parameter, $r_{\pi}, r_{y}$ and $r_{\Delta y}$ are the long-run response coefficients of the central bank to inflation, output, and output growth respectively, and $\varepsilon_{r, t}$ is an exogenous AR(1) process capturing shocks to monetary policy.

The uncovered interest parity (UIP) condition is given by

$E_{t} d_{t+1}=r_{t}-r_{t}^{*}+\varepsilon_{d, t}$

where $d_{t}=e_{t}-e_{t-1}$ is the nominal depreciation rate of home currency, $r_{t}^{*}$ is the nominal interest rate set by the central bank of the foreign country, and $\varepsilon_{d, t}$ is an exogenous shock following an AR(1) process that captures currency depreciation and country risk. The real exchange rate is defined as $\operatorname{rer}_{t}=e_{t}+p_{t}^{*}-p_{t}$, which after first-differencing can be written as rer $_{t}-$ rer $_{t-1}=d_{t}+\pi_{t}^{*}-\pi_{t}$. First-differencing the deviations from the law of one price for the imported goods yields

$$
\Lambda_{t}-\Lambda_{t-1}=\pi_{f, t}-\left(d_{t}+\pi_{h, t}^{*}\right)
$$

Similarly, first-differencing the terms-of-trade yields

$s_{t}-s_{t-1}=\pi_{f, t}-\pi_{h, t}$.

The feasibility condition for the domestic economy is given by 
$y_{t}=\gamma_{c} \frac{C}{Y} c_{h, t}+\gamma_{i} \frac{I}{Y} i_{h, t}+\frac{G}{Y} \varepsilon_{g, t}+\left(1-\gamma_{c}^{*}\right) \frac{C^{*}}{Y^{*}} c_{f, t}^{*}+\left(1-\gamma_{i}^{*}\right) \frac{I^{*}}{Y^{*}} i_{f, t}^{*}$,

where $c_{f, t}^{*}$ and $i_{f, t}^{*}$ are exports from the home country to the foreign country, and $\varepsilon_{g, t}$ is government expenditure which is given by an AR(1) process. ${ }^{\mathbf{6}}$

For each of the equilibrium conditions (1)-(24), except for the UIP condition (21), there is a corresponding equation for the foreign economy where the foreign variables and parameters are now designated with an asterisk. The UIP condition (21), as well as the currency depreciation variable, $d_{t}$, and currency depreciation risk shock, $\varepsilon_{d, t}$, are common to both countries. ${ }^{7}$ Also note that since we defined the exchange rate in units of home currency per foreign currency, the foreign equivalent of equation (22) is as follows:

$$
\Lambda_{t}^{*}-\Lambda_{t-1}^{*}=\pi_{f, t}^{*}+d_{t}-\pi_{h, t}
$$

\section{Data and estimation}

\subsection{Data and Estimation}

We follow Smets and Wouters (2007), and estimate the model parameters using Bayesian likelihood methods. ${ }^{8}$ The model includes 21 shocks in total; there is a currency depreciation risk shock which is common to both countries, and each country has 3 demand shocks (consumption, investment and government expenditure), 1 productivity shock, 3 cost-push shocks (home-goods

\footnotetext{
${ }^{6}$ Note that model consistent gross domestic product (GDP) includes the mark-up of importer intermediaries over import prices as well as the value of domestic output. Since this mark-up does not contribute significantly to the variation in GDP, we treat domestic output as GDP in what follows. Also note that technically, the feasibility condition of the model should also include the consumption of entrepreneurs who do not survive the period, real costs incurred due to the utilization of capital, and costs of financial intermediation. We ignore these components since they are small.

${ }^{7}$ To close the model, we include the net foreign asset position in the interest rate parity equation. This position is a function of the trade balance and the net foreign asset position in the previous period. Following the standard practice, we set the coefficient of the net foreing asset position in the interest rate parity equation to a small value.

${ }^{8}$ The use of Bayesian priors have become commonplace in the literature due to the scarcity of macroeconomic data and identification problems. See An and Schorfheide (2007) and Fernández-Villaverde (2010) for more on Bayesian estimation of DSGE models. We use Dynare to estimate and simulate our model.
} 
price, imported-goods price and wage), and 3 financial shocks (a monetary shock, an external finance premium shock and a net worth shock).

Following Gilchrist et al. (2009), we shut down the investment shocks in both economies since these present an identification problem for the role of financial shocks. Accordingly, we use 19 quarterly data series in our estimation from the U.S. and the Euro zone, for the period 1995q1 to 2009q3. The data series (and their model counterparts) are, the nominal depreciation rate of U.S. dollar against the Euro $\left(d_{t}\right)$, and 10 data series each for the U.S. and 8 data series for the Euro zone; namely real output $\left(y_{t}, y_{t}^{*}\right)$, real consumption $\left(c_{t}, c_{t}^{*}\right)$, real investment $\left(i_{t}, i_{t}^{*}\right)$, real government expenditure $\left(g_{t}, g_{t}^{*}\right)$, labor hours $\left(l_{t}, l_{t}^{*}\right)$, the real wage rate $\left(w_{t}, w_{t}^{*}\right)$, consumer price inflation $\left(\pi_{t}, \pi_{t}^{*}\right)$, the short-term nominal interest rate targeted by the central bank $\left(r_{t}\right)$, the external finance premium $\left(E_{t} r_{k, t+1}-r_{t}\right)$, and the real stock market index $\left(n_{t}, n_{t}^{*}\right) .{ }^{9}$ The external finance premium was proxied by the spread between corporate bonds (Baa rated for the U.S.) following Gilchrist et al. (2009). Similarly, the net worth of entrepreneurs in each country was identified by the value of the stock market (S\&P 500 for the U.S. and the Dow Jones Euro Stoxx 50 Price Index for the Euro zone) as in Christiano et al. (2010). All data series were seasonally adjusted (if needed), first-differenced (except for the depreciation rate, the inflation rate, the nominal interest rate, and the external finance premium), and demeaned prior to estimation. ${ }^{10}$ Appendix A contains further information regarding the data series used in the estimation.

\subsection{Calibrated Parameters}

\footnotetext{
${ }^{9}$ The real wage rate and the real stock market index were obtained by deflating their corresponding nominal series with the consumer price deflator, in line with the inflation series used in the estimation. The quarterly depreciation rate, inflation rate and the interest rates refer to quarterly non-annualized rates in accordance with the model.

${ }^{10}$ In other words, we specify another set of variables in the model which are consistent with the first-differenced observed variables.
} 
Since the data used in the estimation do not contain information about parameters that determine the first moments of model variables, we calibrated some of the level parameters prior to estimation to get more reasonable steady-states (Smets and Wouters, 2007, and Alpanda, 2012). We set these calibrated parameters to identical values for both countries.

The population growth factor, $\eta$, and the per-capita growth of output, $\gamma$, are set to 1.0025 and 1.005 implying (near) $1 \%$ population growth and $2 \%$ output growth on an annual basis. The adjusted time-discount factor, $\tilde{\beta}$, is set to 0.99 which implies a (near) $4 \%$ annualized real interest rate (i.e. risk-free rate) along the balanced growth path of the model. ${ }^{11}$ We set the capital share parameter in the production function, $\alpha$, to 0.3 which implies a steady-state share of labor income of $70 \%$. The depreciation rate of capital, $\delta$, is set to 0.025 which implies a (near) $10 \%$ annual depreciation rate. We assume that the share of government expenditure in total output along the steady-state, $G / Y$, is 0.2 . We also set the intertemporal elasticity of substitution, $\sigma$, to 1 implying logarithmic utility with respect to consumption. The steady-state wage mark-up, $\phi_{w}$, is set to 1.5 as in Smets and Wouters (2007).

Following Gilchrist et al. (2009) we set the steady-state ratio of the capital stock to net worth of entrepreneurs, $K / N$ to 1.7 implying a debt-equity ratio of 0.7 at the steady-state. Also following Gilchrist et al. (2009), we set the survival probability of entrepreneurs, $\gamma_{e}$, equal to 0.99. We set the home-bias parameters, $\gamma_{c}$ and $\gamma_{i}$, to 0.9 implying $10 \%$ import (and export) to output ratio along the steady-state. The intratemporal elasticity of substitution parameters in the consumption and investment aggregators, $\lambda_{c}$ and $\lambda_{i}$, are set equal to 1 and 0.25 , respectively, following Gertler et al. (2007).

\footnotetext{
${ }^{11}$ Note that we do not need to set a value for the actual time-discount factor, $\beta$, which is related to the adjusted factor with $\widetilde{\beta}=\beta \eta \gamma^{1-\sigma}$, since $\beta$ does not enter any of the log-linearized conditions by itself.
} 


\subsection{Prior Distributions}

The prior distributions for the parameters are listed in Tables 1 and 2 for home-country and foreign-country parameters respectively. We used priors similar to Smets and Wouters (2007) and Gilchrist et al. (2009) for the parameters that are not related to the open economy features of the model.

The habit parameter, $\lambda$, has a beta-distribution prior with a mean of 0.7 and a standard deviation of 0.1 . The parameter $\sigma_{l}$ has a normal prior with a mean of 2 (reflecting a Frischelasticity of labor supply of 0.5 ) and a standard deviation of 0.75 . The labor level parameter in the household utility function, $\xi$, is not estimated, but is restricted to equal the following expression to ensure that labor services, $l$, is equal to 1 at the steady-state:

$$
\xi=\frac{(1-\alpha)}{\phi_{w}(1-\lambda / \gamma)(C / Y)}
$$

The capacity utilization elasticity parameter, $\psi$, has a beta prior with mean 0.5 (which implies unit elasticity of utilization with respect to the marginal product of capital) and standard deviation 0.1. The investment adjustment-cost parameter, $\varphi$, has a normal prior with mean 4 (reflecting an elasticity of investment with respect to the price of capital of about 0.125 ) and standard deviation 1.5. The Calvo parameters regulating price and wage stickiness, $\xi_{h}$, $\xi_{f}$ and $\xi_{w}$, all have beta priors with mean 0.5 (i.e. an average of 2-quarter price and wage stickiness)

and standard deviation 0.1 . The price and wage indexation parameters, $l_{h}, l_{f}$ and $t_{w}$, have beta priors with a mean 0.5 and standard deviation of 0.15 . The price mark-up at the steady-state, $\phi_{p}$, is assumed to have a normal prior with mean 1.25 and standard deviation 0.1 . As in Gilchrist et 
al. (2009), the elasticity of the external finance premium to leverage, $\chi$, is assumed to be betadistributed with a mean of 0.07 and a standard deviation of 0.02 .

For the Taylor rule parameters, we assume that the prior for the long-run inflation reaction coefficient, $r_{\pi}$, has a normal distribution with a mean of 1.5 and standard deviation 0.25. Similarly, the long-run reaction coefficient on output and output growth, $r_{y}$ and $r_{\Delta y}$, have normal distributions with mean 0.25 and standard deviation 0.12. The prior for the interest rate smoothing parameter, $\rho$, has a normal distribution with mean 0.75 and standard deviation 0.1 .

The priors for the autoregressive and moving average terms in all shocks have beta distributions with mean 0.5 and standard deviation 0.2. The priors for the standard deviations of all the shocks are also fairly uninformative, with inverse-gamma distributions with mean $0.5 \%$ and infinite variance. The prior distributions along with the posterior estimates are displayed in Table $1^{12}$

\section{Results}

Figures 2, 3 and 4 display the responses (along with the 95\% confidence bands) from the estimated baseline model to monetary policy, credit supply and net worth shocks, respectively. The domestic variables' responses to these shocks have the expected signs and are significant in general. In response to a monetary policy shock, both domestic and export demand decreases. This decrease in export demand and lower domestic prices (despite a stronger U.S. dollar) prompts a drop in foreign output, makes foreign entrepreneurs more leveraged (due to a decrease in asset prices and net worth) and increases the risk premium they face. This financial response

\footnotetext{
${ }^{12}$ Although the posterior estimated for the two regions is similar, in each simulation we find that the financial leverage elasticity parameter, $\chi$, the wage indexation parameter, $l_{w}$, the habit persistence parameter, $\lambda$, and the investment adjustment cost parameter, $\varphi$ are higher for the Euro Area economy. We also observe that the posterior mean values are often different from their prior values thus suggesting that the dataset used is informative.
} 
amplifies the initial, foreign-trade-induced drop in output. Similar responses and the amplification mechanism are observed when there is a domestic net worth and credit supply shock.

One common aspect of these simulations is that the impact on foreign variables is typically small compared to the magnitude of the domestic variable responses. For example, in response to a 100 basis point, annualized U.S. interest rate shock, the drop in U.S. output is approximately 12 times larger than the drop in Euro Area output. Similarly, the impulse responses in Figures 3 and 4 indicate that U.S. output responses are approximately 5 times larger in magnitude when there is a U.S. net worth and credit supply shock. This disparity in output responses is also observed when other U.S. nominal and real shocks (except exchange rate and foreign-goods price shocks) are considered as in Figure 5. Finally, we should note that there is a similar disparity between the responses of U.S. and Euro Area variables other than output. ${ }^{13}$

The low sensitivity of Euro Area macroeconomic variables to U.S. shocks that we find in our baseline model is hard to reconcile with the high levels of cross-regional correlation observed between most macroeconomic variables in the data. The first column of Table 2 reports some of the correlation coefficients that are computed using data from 1995q1 to 2009q3 (our sample period). The correlations between both real and nominal variables of the two regions, except for wages, are not negligible and they are positive. Consistent with the impulse responses, the correlation coefficients obtained from the calibrated baseline model simulations, reported in the second column of Table 2, are small and sometimes have the opposite sign compared to the data. In particular, the baseline model is unable to generate the high levels of correlation between U.S. and Euro Area output. In the calibrated model simulations, we set the standard deviation

\footnotetext{
${ }^{13}$ Given space limitations, we do not report these simulation results. These results are available if requested.
} 
and persistence parameter of each shock, U.S. and Euro Area shock, to 0.01 and 0.9, respectively. In doing so, we do not allow for cross-regional correlation between the shocks. When we relax this assumption by allowing for financial shock (interest rate, net worth and cost of capital) correlation coefficients to equal 0.5 and 1 , we find that model moments, although still considerably smaller most of the time, become closer to those observed in the data.

To more rigorously investigate the role of cross-regional correlation, we proceed by estimating the model and the shock processes by allowing for cross-regional correlation in financial shocks. In other words, we estimate the correlation of these shocks instead of arbitrarily calibrating them to higher values and we then quantify the impact of correlated shocks on Euro Area responses. The posterior distributions reported in Table 1 indicate that financial shock correlations, similar to the financial variable correlations in the data, are positive and not negligible. We find that U.S. and Euro Area, interest rate, net worth and cost of capital shock correlation coefficient values are $0.6245,0.7392$ and 0.5361 , respectively.

Impulse responses obtained from this model suggests that these non-negligible shock correlations have an important impact on how the Euro Area economy responds to U.S. shocks. In Figure 5, for example, we report the responses to an annualized 100 basis points U.S. interest rate shock. The central result is that allowing for financial shocks to be correlated, despite having a smaller impact on U.S. macroeconomic variables, significantly amplifies the Euro Area impulse responses. We also test the significance of the financial accelerator mechanism for the cross country transmission of monetary policy shocks in the baseline model by shutting off the financial accelerator mechanism (setting $\chi$ equal to arbitrarily small value). The results, also displayed in Figure 6, suggest that although responses (especially for domestic variables) are smaller without the financial accelerator, the decrease in the response of foreign variables is 
relatively small. This result suggests that the widely-accepted advantages of the financial accelerator mechanism in adding amplification and persistence to model responses that are needed to match the behaviour of macroeconomic variables in the U.S. economy are not as critical for international transmission of U.S. shocks. In the next section we show how a financial accelerator mechanism, generated by financial frictions in international credit markets that are thus common to both regions, can significantly amplify the international transmission of U.S. shocks and improve the model's ability to match cross-regional output correlation.

Finally, we draw similar conclusions by comparing the historical decompositions from the baseline model and the model with exogenous financial correlation. These decompositions, displayed in Figure 7, show that in the model with financial correlation U.S. shocks (consumption, government expenditure, productivity, monetary, home-goods price, importedgoods price, wage, interest rate, cost of capital and net worth shocks) explain a much larger share of Euro Area output variation compared to the baseline model (especially before and during the recent financial crisis).

\section{Cross-regional bank lending}

In this section we extend the baseline model to endogenously generate a cross-regional correlation between credit spreads. We do so by assuming that banks lend in each region and that they cannot raise loanable funds at the risk free rate and have to pay a premium that depends on their financial leverage. These assumptions allow us to link credit spreads across regions since both shocks to economic activity and shocks to the banks' net worth affect their finance costs which in turn affects the credit spreads in both regions.

We begin extending our model by assuming that there is a continuum of identical global bank holding companies (hereafter, BHCs) that lend both in the U.S. and in the Euro Area. These 
BHCs lend through their subsidiaries which offer contracts to entrepreneurs that are defined by the two equations below.

$$
\begin{aligned}
& {\left[1-F\left(\bar{a}_{i}\right)\right]\left(R_{j t}^{b}+v_{i}\right)\left(Q_{i t} K_{i t}-N_{i t}\right)+(1-\mu) \int_{0}^{\bar{a}_{i}} a_{i} E_{t} R_{i t+1}^{k} Q_{i t} K_{i t} d F\left(a_{i}\right)=R_{j t}^{b}\left(Q_{i t} K_{i t}-N_{i t}\right)} \\
& \bar{a}_{i} R_{i t+1}^{k} Q_{i t} K_{i t}=\left(R_{j t}^{b}+v_{i}\right)\left(Q_{i t} K_{i t}-N_{i t}\right)
\end{aligned}
$$

where $a_{i}$ is the idiosyncratic returns to capital shock (lognormally distributed) that entrepreneur $i$ faces and $F\left(a_{i}\right)$ is the lognormal c.d.f. . If this shock is smaller than the cutoff value, $\bar{a}_{i}$, defined in equation (28), the entrepreneur defaults and the BHC (indexed by $j$ ) recovers the remaining funds of the entrepreneur after paying bankruptcy costs (governed by the parameter, $\mu$ ). To compensate these bankruptcy costs entrepreneur $i$ pays a borrowing premium of $v_{i}$ that is an increasing function of her financial leverage. This premium allows BHC $j$ to equate its returns from lending to its costs of raising loanable funds, $R_{j t}^{b}$ so that

$$
E_{t} R_{t+1}^{k}=R_{j t}^{b} v^{e}\left(\frac{Q_{t} K_{t}}{N_{t}}\right)
$$

Here, we are additionally assuming that each $\mathrm{BHC}$, in each region, is able to diversify the idiosyncratic risk over the continuum of entrepreneurs that they lend to and collect the rate of return $R_{j t}^{b}$. Equations (27) and (28) are similar to those used to derive the cost of capital condition in Section 2 (equation (12)) and equation (29) is similarly obtained by aggregating over the continuum of entrepreneurs. We deviate from this usual practice by assuming that the BHCs cannot raise loanable funds at the risk free rate and they have to borrow from wholesale credit markets. In doing so, BHCs pay a borrowing premium of $R_{j t}^{b}-R_{t}^{w}$ (where $R_{t}^{w}$ is the wholesale borrowing rate). To simplify computations, we assume that the consumers in each 
region pool their savings in their local wholesale market and collect the wholesale market rate of return. These funds are then borrowed by the BHCs to finance their lending in that region (together with their net worth). More specifically, let $D_{t}$ and $D_{t}^{*}$ denote the total savings of consumers in the two regions, respectively and $N B_{t}$ denote the BHCs' net worth, then $Q_{t} K_{t}-N_{t}+e_{t}\left(Q_{t}^{*} K_{t}^{*}-N_{t}^{*}\right)=D_{t}+e_{t} D_{t}^{*}+N B_{t}$. Here we reasonably assume that in each region domestic monetary policy is the main determinant of the wholesale borrowing rates and thus $R_{t}^{w}$ is equal to the policy rates ( $R_{t}$ and $R_{t}^{*}$ for the U.S. and the Euro Area, respectively) in each region.

In the wholesale market the source of financial friction is that the BHCs experience an idiosyncratic net worth shock (denoted by $b_{j}$ and lognormally distributed across BHCs with an expected value of 1) after entrepreneurs pay back their loans and the BHCs pool the revenues from their subsidiaries. Similar to the terms of the entrepreneurs' financial contract, if this shock is below a certain cutoff value, the BHC fails to pay back its loans and a new BHC company replaces it. The wholesale market then incurs bankruptcy costs in recovering a fraction of the bad loans. To compensate for these contingent bankruptcy costs, BHCs pay a premium over the wholesale rate. Given these assumptions, the following two equations define the contract that the BHCs agree to:

$$
\begin{aligned}
& {\left[1-F\left(\bar{b}_{j}\right)\right]\left(R_{t}^{w}+x_{j}\right)\left(B B_{j t}-N B_{j t}\right)+\left(1-\mu^{b}\right) \int_{0}^{\bar{b}_{i}} b_{j}\left(R_{t}^{w}+x_{j}\right) B B_{j t} d F\left(b_{j}\right)=R_{t}^{w}\left(B B_{j t}-N B_{j t}\right)} \\
& \left(R_{t}^{w}+x_{j}\right)\left(B B_{j t}-N B_{j t}\right)=\bar{b}_{j}\left(R_{t}^{w}+x_{j}\right) B B_{j t}
\end{aligned}
$$

where $B B_{j t}=\gamma_{j}\left[Q_{t} K_{t}-N_{t}+e_{t}\left(Q_{t}^{*} K_{t}^{*}-N_{t}^{*}\right)\right]$ and $x_{j}$ is the premium BHC $j$ pays. $\gamma_{j}$ is BHC $j$ 's share of lending and its share of the total net worth of all the BHCs. Given that the BHCs are 
identical in every aspect except the idiosyncratic shock, as in the contract with the entrepreneurs, every BHC is charged the same premium. Therefore, let $R_{t}^{b}=R_{t}^{w}+x$ then the BHCs' borrowing costs can be derived by substituting equation (31) into equation (30),

$$
R_{j t}^{b}=R_{t}^{w} v^{b}\left(\frac{B B_{j t}}{N B_{j t}}\right)
$$

where $v^{b}\left(\frac{B B_{j t}}{N B_{j t}}\right)=\left(\left[1-F\left(1-\frac{N B_{j t}}{B B_{j t}}\right)\right]\left(1-\frac{N B_{j t}}{B B_{j t}}\right)+\left(1-\mu^{b}\right) \int_{0}^{1-\frac{N B_{j t}}{B B_{j t}}} b_{j} d F\left(b_{j}\right)\right)^{-1}\left(1-\frac{N B_{j t}}{B B_{j t}}\right)$.

Since the borrowing premium, the cutoff value of the idiosyncratic net worth shock and the leverage for every BHC is the same, the net worth of the BHCs can be aggregated and its evolution can be derived as follows: ${ }^{14}$

$$
N B_{t+1}=\gamma^{b}\left[1-F\left(\bar{b}_{j}\right)\right] R_{t}^{b} N B_{t}+\left[\Phi\left(\frac{\sigma^{2} / 2-\ln \left(\bar{b}_{j}\right)}{\sigma}\right)-\left[1-F\left(\bar{b}_{j}\right)\right]\right] R_{t}^{b} B B_{t},
$$

where the survival rate $\gamma^{b}$ is similarly needed to prevent BHCs from accumulating enough net worth and to motivate external borrowing, and $\Phi(\cdot)$ and $F($.$) are the standard normal and$ lognormal c.d.f., respectively. ${ }^{15}$ The bankruptcy costs associated with BHC borrowing generate a wedge between the wholesale rate and the BHCs' cost of borrowing. The cost of capital for the entrepreneur can then be derived as follows:

${ }^{14}$ BHC specific net worth equations $N B_{j t+1}=\int_{b_{j}}^{\infty}\left(b_{j} R_{j t}^{b} B B_{j t}-R_{j t}^{b}\left(B B_{j t}-N B_{j t}\right)\right) d F\left(b_{j}\right) \quad$ are aggregated (assuming that the expected value of the idiosyncratic shock is equal to 1) to derive equation (33). The two terms in the net worth expression are the returns from the loans and the payments made to the consumers, respectively, given that the bank does not default.

${ }^{15}$ The evolution of BHC net worth can be presented in the following linearized form: $n b_{t+1}=\mu_{1} n b_{t}+\mu_{2} b b_{t}$. 
$E_{t}\left[R_{t+1}^{k}\right]=R_{t}^{w} v^{b}\left(\frac{B B_{t}}{N B_{t}}\right) v^{e}\left(\frac{Q_{t} K_{t}}{N_{t}}\right)$

In Appendix B, we derive this equation from the optimization problem of the BHC. The key feature of this problem is that the BHC, in determining the lending premium, not only considers the leverage of the borrower but also its own leverage (since it affects its own borrowing costs). In Appendix B we also linearize equation (34) to produce the following cost of capital condition for the domestic economy (U.S.):

$E_{t} r_{t+1}^{k}=\frac{R(Q K-N)}{B B} r_{t}+\chi_{1}\left(q_{t}+k_{t}-\frac{N}{Q K} n_{t}\right)+\chi_{2}\left(e_{t}+q_{t}^{*}+k_{t}^{*}-\frac{N^{*}}{Q^{*} K^{*}} n_{t}^{*}\right)-\chi_{3} n b_{t}$

where uppercase letters represent steady state values of the variables. According to this equation, the level of credit demand in a given region and the net worth of the BHCs affects the credit spreads in both regions. One desirable feature of the changes we made in this section is that they do not confound the analysis significantly. Compared to the baseline model, we only modify the cost of capital equation for each region and add the equation that describes the evolution of BHC net worth.

\subsection{Results}

We begin our investigation of the results by comparing the variable moments generated by the calibrated-model to those observed in the data. In Table 2 we observe that the model with crossregional banking (endogenous correlation) does a much better job of replicating data moments compared to the baseline model without financial correlation. We observe that allowing for financial correlation in the baseline model only improves the model's ability to match financial data moments and the real variable moments from the model with cross-regional banking are 
closer to those observed in the data. ${ }^{16}$ We should also mention that when we allow for interest rate shocks and net worth shocks to be correlated in addition to the endogenous correlation of credit spreads, we find a much higher correlation between the financial variables of the two regions.

We proceed by measuring the Euro Area responses to U.S. financial shocks and comparing the magnitude of these responses across the different models that we described above. The results displayed in Figure 8 show that the Euro Area responses to a 100 basis point annualized U.S. interest rate shock and a 1 percent U.S. net worth shock in the model with crossregional banking are considerably larger in magnitude compared to the baseline model responses. These results suggest that an important share of the foreign spill-over effects of domestic shocks can be explained by the correlation of credit spreads endogenously determined by the global scale of banking activity.

The mechanism that generates a large Euro Area response in the model is the countercyclicality of BHCs' borrowing premium. In response to a U.S. interest shock, domestic and foreign output and asset prices decrease. The decrease in asset prices causes entrepreneurs' net worth to decrease in both regions. The entrepreneurs' thus rely more on external funding. This is because the drop in net worth is larger than the drop in asset prices and capital. So far, these responses are the same as those obtained from the baseline model. In the model with crossregional banking, the BHCs borrow more from the wholesale market to provide funding to the entrepreneurs (mostly to U.S. entrepreneurs since the initial Euro Area response is small). An increase in loans in turn, increases BHCs’ net worth. The latter affect, however, is smaller than

${ }^{16}$ In comparing the simulation results, we set the intertemporal elasticity of substitution to 1 following the common practice in the literature. Our estimation results in Table 1, however, indicate that this elasticity parameter may be closer to 1.5 than it is to 1 . When we set the parameter to 1.5 , the models generated consumption correlations are much closer to the correlation in the data. 
the increase in loans because BHCs recover only a fraction of the loans and the increase in interest rates prompt higher default rates. As a result BHCs become more leveraged and thus face higher external borrowing premiums. These BHC specific responses are displayed in Figure 8 (along with 95\% confidence bands). The more central result for this paper is that the response of BHC leverage, although caused by a U.S. shock, affects both regions. In other words, the increase in BHC borrowing premiums are transmitted to the borrowing premiums in each region and borrowing premiums increase and output decreases by more than in the baseline model.

The countercyclicality of BHC risk premium is also observed when there is a U.S. net worth shock. An increase in U.S. entrepreneurs' net worth decreases external borrowing of both the entrepreneurs and the BHCs. Despite the decrease in BHC net worth, BHCs become less leveraged and face lower risk premiums. The drop in the premium amplifies the initial positive response of Euro Area output by decreasing Euro Area entrepreneurs' borrowing premium. We find that this amplification mechanism generates larger Euro Area responses compared to the baseline model for the other shocks (nominal and real) in the model as well. The responses to a 1 percent U.S. productivity, consumption and home-goods price shocks are displayed in Figure 9 demonstrate this disparity. However, we should mention that, compared to the model with ad hoc financial correlation, the responses are sometimes higher (as in the responses to a U.S. net worth shock) and sometimes lower (as in the responses to a U.S. interest rate shock).

\section{Conclusion}

This paper demonstrated that a two region open economy model where the regions are only linked through trade and bond markets is unable to replicate the high degree of correlation between the U.S. and the Euro Area macroeconomic variables observed in the data. Allowing for cross-regional correlation of financial shocks considerably amplified the Euro Area variables’ 
response to U.S. financial shocks. The magnitude of this amplification was much larger than the international effects of the widely-used financial accelerator mechanism. Focusing on one reason why financial shocks in the two could be correlated, we then found that the global scale of banking activity and its symmetric effects on the cost of capital in each region could produce a much larger correlation of macroeconomics across the two regions compared to the baseline model.

One advantage of estimating the model was that it allowed us to identify the magnitudes and the persistence of the shocks impacting the two regions (along with estimating the nonstandard parameters in the model). Although adding a wide range of rigidities also allowed us to match some of the characteristics of impulse responses in the data, it considerably increased the number of variables and parameters. Given the large dimension of the model, convergence in the estimation process was difficult and our ability to incorporate other characteristics of international financial markets that can also explain the high cross-regional correlation of variables was constrained. For example, we did not investigate the impact of financial linkages such as consumers' cross-equity holdings and banks' international asset holdings (including derivatives). It would be interesting for future research to build these components into a simpler version of our model to compare their relative importance for international financial shock transmission.

In the model the BHCs' leverage and the frictions in credit markets affected the economy mostly through the amount of loans supplied. We know that the more important determinant of the negative supply side effect during the recent financial crisis was due to the decrease in BHCs' net worth. In this paper, we did not simulate the effects of BHCs' net worth shocks since we did not have the data to estimate the shock processes. It would be an interesting, yet 
challenging, next step to identify the global BHCs in the U.S. and Euro Area, and to quantify the impact of BHC net worth shocks (perhaps due to a decrease in the value of their assets) on the two regions.

Finally, we should note that in the extended version of our model we assumed that every bank/BHC has global operations. Although banks (mostly large banks) that do most of the lending in the U.S. and the Euro Area have subsidiaries abroad and a large number of small/domestic banks have a large/global BHC as their high holder, it would be a natural extension of our analysis to incorporate domestic banks into the model and to measure the degree to which financial shocks are transmitted to the domestic and the foreign economies through domestic and global banks.

\section{REFERENCES}

Alpanda, S. (2012). "Identifying the Role of Risk Shocks in the Business Cycle Using Stock Price Data," Economic Inquiry, forthcoming.

Alpanda, S. and Aysun, U. (2012). "Global Banking and the Balance Sheet Channel of Monetary Transmission,” International Journal of Central Banking, 8(3), 141-175.

An, S. and Schorfheide, F. (2007). Bayesian analysis of DSGE models. Econometric Reviews, 26, 113-172.

Ashcraft, A. (2006). "New Evidence on the Lending Channel," Journal of Money, Credit and Banking, 38(3), 751-776.

Baxter, M. and Crucini, M. (1995). "Business cycles and the asset structure of foreign trade," International Economic Review, 36, 821-854.

Bernanke, B., Gertler, M. and Gilchrist, S. (1999). The Financial Accelerator in a Quantitative Business Cycle Framework. In Taylor, J.B. and Woodford, M., ed., Handbook of Macroeconomics. 1C, 1341-1393. Amsterdam: Elsevier Science, North-Holland.

Bruno, V. and Shin, H. (2012). "Capital flows, cross-border banking and global liquidity," mimeo, July.

Buch, C.M. (2000). "Why Do Banks Go Abroad? Evidence from German Data," Financial Markets, Institutions and Instruments, 9(1), 33-67.

Calvo, G. (1983). "Staggered prices and in a utility-maximizing framework," Journal of Monetary Economics, 12(3), 383-398.

Carlstrom, C.T., and Fuerst, T.S. (1997). "Agency Costs, Net Worth, and Business Fluctuations: A Computable General Equilibrium Analysis,” American Economic Review, 87, 893-910.

Cetorelli, N. and Goldberg, L.S. (2012). "Banking Globalization and Monetary Transmission," The Journal of Finance, 67, 1811-1843.

Christiano, L.J., Eichenbaum, M. and Evans, C.L. (2005). "Nominal Rigidities and the Dynamic Effects of a Shock to Monetary Policy,” Journal of Political Economy, 113, 1-45. 
Christiano, L.J., Motto, R. and Rostagno, M. (2010). "Financial Factors in economic Fluctuations,” Working Paper Series 1192, European Central Bank.

Dahl, D., R. E. Shrieves, and M. F. Spivey. 2002. "Financing Loan Growth at Banks.” Journal of Financial Services Research 22(3), 189-202.

Davis, J. S. (2011). "The adverse feedback loop and the effects of risk in both the real and financial sectors,” working paper, Vanderbilt University.

De Haas, R. and Van Lelyveld, I. (2006). "Foreign Banks and Credit Stability in Central and Eastern Europe. A Panel Data Analysis,” Journal of Banking and Finance 30(7), 1927-1952.

- (2010). "Internal Capital Markets and Lending by Multinational Bank Subsidiaries," Journal of Financial Intermediation, 19(1), 1-25.

Devereux, M.B. and Yetman, J. (2010). "Leverage constraints and the international transmission of shocks," Journal of Money, Credit and Banking 42, 71-105.

Faia, E. (2007). "Finance and international business cycles,” Journal of Monetary Economics, 54(4), 1018-1034.

Fernández-Villaverde, J. (2010). “The econometrics of DSGE models,” SERIEs, Spanish Economic Association, 1(1), 3-49.

Gertler, M., Gilchrist, S. and Natalucci, F.M. (2007). "External Constraints on Monetary Policy and the Financial Accelerator,” Journal of Money, Credit and Banking, 39, 295-330.

Gertler, M., and Karadi, P. (2011). “A Model of Unconventional Monetary Policy,” Journal of Monetary Economics, 58, 17-34.

Gilchrist, S., Yankov, V. and Zakrajsek, E. (2009). "Credit market shocks and economic fluctuations: Evidence from corporate bond and stock markets," Journal of Monetary Economics, 56(4), 471-493.

Goldberg, L. (2002) “When Is U.S. Bank Lending to Emerging Markets Volatile?” In Preventing Currency Crises in Emerging Markets, ed. S. Edwards and J. A. Frankel, 171-196. National Bureau of Economic Research, Inc.

Jeanneau, S. and Micu, M. (2002). "Determinants of International Bank Lending to Emerging Market Countries,” BIS Working Paper No. 112.

Justiniano, A. and Preston, B. (2010). Monetary Policy and Uncertainty in an Empirical Small Open Economy Model. Journal of Applied Econometrics, 25(1), 93-128.

Kashyap, A., and Stein, J. (2000). "What Do a Million Observations on Banks Say about the Transmission of Monetary Policy?” American Economic Review, 90(3), 407-428.

Loutskina, E. and Strahan, P.E. (2009). "Securitization and the Declining Impact of Bank Finance on Loan Supply: Evidence from Mortgage Originations,” Journal of Finance, 64(2), 861-889.

Kollmann, R. (1995). “Consumption, real exchange rates, and the structure of international asset markets,” Journal of International Money and Finance, 14, 191-211.

(2012). "Global Banks, Financial Shocks and International Business Cycles: Evidence from an Estimated Model,” Centre for Economic Policy Research, Discussion Paper, 8985.

Kollmann, R., Enders, Z. and Müller, G. (2011). “Global banking and international business cycles,” European Economic Review, 55, 407-426.

Martinez Peria, M. S., Powell, A. and Hollar, I.V. (2002). "Banking on Foreigners: The Behavior of International Bank Lending to Latin America, 1985-2000,” World Bank Policy Research Working Paper No. 2893.

Meh, C., and Moran, K. (2010). "The Role of Bank Capital in the Propagation of Shocks," Journal of Economic Dynamics and Control, 34, 555-576. 
Morgan, D. P. and Strahan, P.E. (2004). "Foreign Bank Entry and Business Volatility: Evidence from U.S. States and Other Countries.” In Foreign Banking Market Structure and Monetary Policy, ed. Luis Ahumada and J. Fuentes. Santiago: Central Bank of Chile.

Morgan, D. P., Rime, B. and Strahan, P.E. (2004). "Bank Integration and State Business Cycles,” Quarterly Journal of Economics, 119(4), 1555-1584.

Schmitt-Grohe, S. and Uribe, M. (2005). "Closing small open economies," Journal of International Economics, 61, 163-185.

Shapiro, M., and Watson, M. (1989). “Sources of Business Cycles Fluctuations,” NBER Working Paper No. 2589.

Smets, F. and Wouters, R. (2007). "Shocks and frictions in US business cycles: A Bayesian DSGE approach,” American Economic Review, 97, 586-606.

Yao, W. (2012). "International Business Cycles and Financial Frictions," Bank of Canada Working Paper, 2012-19.

Zimmermann, C. (1997). "International real business cycles among heterogeneous countries," European Economic Review, 41(2), 319-356. 
APPENDIX A. Data definitions and sources

\begin{tabular}{|c|c|c|c|}
\hline & Variable & Description & Data Source \\
\hline \multicolumn{4}{|c|}{ U.S. data } \\
\hline & Output & Real Gross Domestic Product & Federal Reserve Economic Data \\
\hline & Consumption & Real Personal Consumption Expenditures & Federal Reserve Economic Data \\
\hline & Investment & Real Private Fixed Investment & Federal Reserve Economic Data \\
\hline & $\begin{array}{l}\text { Government } \\
\text { Expenditures }\end{array}$ & Real Government Consumption Expenditures \& Gross Investment & Federal Reserve Economic Data \\
\hline & Employment & Average Weekly Hours: Total Private Industries & Federal Reserve Economic Data \\
\hline & Wages & Average Hourly Earnings: Total Private Industries & Federal Reserve Economic Data \\
\hline & $\begin{array}{l}\text { Monthly stock } \\
\text { market data }\end{array}$ & S\&P 500 & Robert Shiller, online data \\
\hline & Bond Yield & Moody's Seasoned Baa Corporate Bond Yield & Federal Reserve Economic Data \\
\hline & GDP Deflator & Gross Domestic Product: Implicit Price Deflator & Federal Reserve Economic Data \\
\hline & CPI & Consumer Price Index For All Urban Consumers: All Items & Federal Reserve Economic Data \\
\hline & Investment Deflator & Gross Private Domestic Investment: Chain-type Price Index & Federal Reserve Economic Data \\
\hline & Interest rate & Federal funds rate & Federal Reserve Economic Data \\
\hline \multicolumn{4}{|c|}{ Euro Area data } \\
\hline & Output & $\begin{array}{l}\text { Euro area } 16 \text { (fixed composition) - Gross domestic product at market } \\
\text { price - Chain linked volumes, reference year } 2000 \text { - ECU/euro - } \\
\text { Seasonally and partly working day adjusted, mixed method of } \\
\text { adjustment }\end{array}$ & European Central Bank \\
\hline & Consumption & $\begin{array}{l}\text { Euro area } 16 \text { (fixed composition) - Final consumption of hous eholds } \\
\text { and NPISH's (private consumption) - Chain linked volumes, reference } \\
\text { year } 2000 \text { - ECU/euro - No adjustment }\end{array}$ & European Central Bank \\
\hline & Investment & $\begin{array}{l}\text { Euro area } 16 \text { (fixed composition) - Gross fixed capital formation - } \\
\text { Chain linked volumes, reference year } 2000 \text { - ECU/euro - No } \\
\text { adjustment }\end{array}$ & European Central Bank \\
\hline & $\begin{array}{l}\text { Government } \\
\text { Expenditures }\end{array}$ & $\begin{array}{l}\text { Euro area } 16 \text { (fixed composition) - Final consumption of general } \\
\text { government - Chain linked volumes, reference year } 2000 \text { - ECU/euro - } \\
\text { No adjustment }\end{array}$ & European Central Bank \\
\hline & Employment & $\begin{array}{l}\text { Employment Euro area } 16 \text { (fixed composition) - Total employment, } \\
\text { domestic - Non monetary - Persons - Seasonally and partly working } \\
\text { day adjusted, mixed method of adjustment }\end{array}$ & European Central Bank \\
\hline & Wages & $\begin{array}{l}\text { Euro } 16 \text { - Compensation Per Employee - Total - Index } 2000 \text { = } 100 \text { - } \\
\text { Seasonally adjusted }\end{array}$ & European Central Bank \\
\hline & $\begin{array}{l}\text { Monthly stock } \\
\text { market data }\end{array}$ & $\begin{array}{l}\text { Stock Index Euro area (changing composition) - Equity/index - Dow } \\
\text { Jones Euro Stoxx } 50 \text { Price Index - Historical close, average of } \\
\text { observations through period - Euro, provided by DataStream }\end{array}$ & European Central Bank \\
\hline & Bond Yield* & Corp bond spreads up to 1 year & International Financial Statistics \\
\hline & GDP Deflator & $\begin{array}{l}\text { Euro area } 16 \text { (fixed composition) - Gross domestic product at market } \\
\text { price - Deflator (ECB compilation) - Euro (estimated) - Seasonally and } \\
\text { partly working day adjusted, mixed method of adjustment }\end{array}$ & European Central Bank \\
\hline & CPI & $\begin{array}{l}\text { Euro area } 16 \text { (fixed composition) - ECB Commodity Price index Euro } \\
\text { denominated, use-weighted, Total non-energy commodity; European } \\
\text { Central Bank; Neither seasonally nor working day adjusted }\end{array}$ & European Central Bank \\
\hline & Investment Deflator & $\begin{array}{l}\text { Euro area } 16 \text { (fixed composition) - Gross fixed capital formation - } \\
\text { Deflator (ECB compilation) - Euro (estimated) - Seasonally and partly } \\
\text { working day adjusted, mixed method of adjustment }\end{array}$ & European Central Bank \\
\hline & Interest rate* & ECB policy rate & European Central Bank \\
\hline
\end{tabular}

Note: Euro Area interest rate and bond spread data were only used when comparing model moments to data moments. 
APPENDIX B. Cost of capital with cross-regional bank lending

In this appendix we derive the cost of capital relationship when there is cross-regional banking by solving the optimization problem of the BHCs. ${ }^{17}$ We begin by defining a BHC's share of revenues as,

$$
\Gamma\left(\bar{a}_{i}\right)=\left[1-F\left(\bar{a}_{i}\right)\right] \bar{a}_{i}+\int_{0}^{\bar{a}_{i}} a_{i} d F\left(a_{i}\right)
$$

Given the BHC's contract with the wholesale market, its optimization problem can be represented as,

$$
\operatorname{Max}_{K} \quad\left[1-\Gamma\left(\bar{a}_{i}\right)\right] R^{k} Q K
$$

s.t. $\quad\left(\Gamma\left(\overline{\mathrm{a}}_{\mathrm{i}}\right)-\mu \int_{0}^{\bar{a}_{i}} a_{i} d F\left(a_{i}\right)\right) R^{k} Q K=R^{w} v^{b}\left(\frac{B B}{N B}\right)(Q K-N)$

Let $u_{1}=\left(\Gamma\left(\overline{\mathrm{a}}_{\mathrm{i}}\right)-\mu \int_{0}^{\bar{a}_{i}} a_{i} d F\left(a_{i}\right)\right)$ then the optimality conditions can be represented as follows:

$\bar{a}_{i}: \quad \lambda=\Gamma^{\prime}\left(\bar{a}_{i}\right) / u_{1}^{\prime}$

$\lambda: \quad u_{1} R^{k} Q K=R^{w} v^{b}\left(\frac{B B}{N B}\right)(Q K-N)$

$K: \quad\left(\left[1-\Gamma\left(\bar{a}_{i}\right)\right]+\lambda u_{1}\right) R^{k}=\lambda R^{w}\left[\frac{v_{k}^{b}}{N B}+v^{b}\right]$

where $B B$ and $N B$ denote the BHCs' total lending and net worth (their expressions are the same as in Section 5) and $v^{b}(x)=\left([1-F(1-x)](1-x)+\left(1-\mu^{b}\right) \int_{0}^{1-x} b_{j} d F\left(b_{j}\right)\right)^{-1}(1-x)$. Let $u_{2}=\left[\frac{\lambda}{1-\Gamma\left(\bar{a}_{i}\right)+\lambda u_{1}}\right]$ then using these conditions we can derive the cost of capital as,

\footnotetext{
${ }^{17}$ To simplify the exposition, we omit the time subscripts.
} 
$R^{k}=u_{2} R^{w} \frac{v_{k}^{b}}{N B}\left(\frac{1}{1-u_{2} u_{1}\left(\frac{1}{1-N / Q K}\right)}\right)$

According to equation (B.6), the BHC not only considers the leverage of the borrower but also how much its own borrowing costs will increase if it lends an additional unit of capital to the entrepreneur. ${ }^{18}$ Equation (B.6) can be expressed in the following linearized form,

$$
r^{k}=\frac{R(Q K-N)}{B B} r+\chi_{1}\left(q+k-\frac{N}{Q K} n\right)+\chi_{2}\left(e+q^{*}+k^{*}-\frac{N^{*}}{Q^{*} K^{*}} n^{*}\right)-\chi_{3} n b
$$

where the upper case and lower case variables denote the steady state values, and the deviations from steady state, respectively and

$$
\begin{aligned}
& \chi_{1}=\left(\frac{R}{B B}+\frac{u_{2} u_{1}}{\left(1-N / Q K-u_{2} u_{1}\right)^{2}}+\frac{\bar{v}_{k}^{b}}{N B}\right) Q K, \quad \chi_{2}=\left(\frac{R^{*}}{B B}+\frac{u_{2} u_{1}}{\left(1-N^{*} / Q^{*} K^{*}-u_{2} u_{1}\right)^{2}}+\frac{\bar{v}_{k}^{b}}{N B}\right) Q^{*} K^{*} \\
& \chi_{3}=1-\frac{\bar{v}_{k}^{b}}{N B} .{ }^{19}
\end{aligned}
$$

${ }^{18}$ Notice here that since the BHC net worth expression in equation (33) in the text does not include the contemporaneous value of the capital stock, it treated as a constant when computing the partial derivative with respect to $k$.

${ }^{19}$ Given that the wholesale market rate is the same when solving for the optimal amount of lending in each region, it can be shown using equations (B.5) and (B.6) that $q^{*}+k^{*}=n^{*}+\frac{Q K N^{*}}{N}\left(1-\frac{N u_{1}^{*} \lambda^{*}}{Q K u_{1} \lambda}\right)^{-2} \frac{u_{1}^{*} \lambda^{*}}{u_{1} \lambda}(q+k-n)$. 
Table 1. Estimates of structural parameters

\begin{tabular}{|c|c|c|c|c|c|c|c|c|c|}
\hline & \multirow[b]{4}{*}{ Prior Densities } & \multicolumn{8}{|c|}{ Posterior Means } \\
\hline & & \multicolumn{8}{|c|}{ 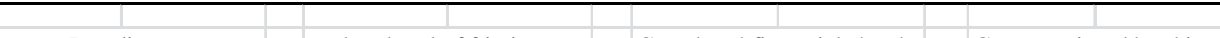 } \\
\hline & & \multicolumn{2}{|c|}{ Baseline } & \multicolumn{2}{|c|}{ low level of frictions } & \multicolumn{2}{|c|}{ Correlated financial shocks } & \multicolumn{2}{|c|}{ Cross-regional banking } \\
\hline & & Home & Foreign & Home & Foreign & Home & Foreign & Home & Foreign \\
\hline$\chi$ & $\mathrm{B}(0.07,0.02)$ & 0.0562 & 0.0228 & - & - & 0.0780 & 0.0214 & - & - \\
\hline$\lambda$ & $\mathrm{B}(0.7,0.1)$ & 0.4739 & 0.9626 & 0.9112 & 0.9804 & 0.7552 & 0.9709 & 0.3671 & 0.9807 \\
\hline$\sigma$ & $\mathrm{N}(1.5,0.37)$ & 1.7026 & 1.0139 & 1.5990 & 1.0159 & 1.4202 & 1.0135 & 1.3606 & 1.0107 \\
\hline$\sigma_{1}$ & $\mathrm{~N}(2,0.75)$ & 1.7008 & 1.2822 & 2.2742 & 2.2772 & 1.3172 & 2.1571 & 2.4597 & 2.1421 \\
\hline$\phi_{p}$ & $\mathrm{~N}(1.25,0.1)$ & 1.1941 & 2.2139 & 1.3053 & 2.1213 & 1.4000 & 2.0773 & 1.2156 & 2.2042 \\
\hline$\psi$ & $\mathrm{B}(0.5,0.2)$ & 0.4516 & 0.9909 & 0.4438 & 0.9868 & 0.6782 & 0.9859 & 0.3307 & 0.9851 \\
\hline$\varphi$ & $\mathrm{N}(4,1.5)$ & 5.4057 & 9.9144 & 3.0146 & 7.9008 & 4.3002 & 9.5117 & 2.9399 & 9.0348 \\
\hline$l_{h}$ & $\mathrm{~B}(0.5,0.15)$ & 0.5658 & 0.3855 & 0.5328 & 0.5264 & 0.4879 & 0.4001 & 0.4465 & 0.3926 \\
\hline$l_{f}$ & $\mathrm{~B}(0.5,0.15)$ & 0.4967 & 0.4090 & 0.5198 & 0.3609 & 0.5041 & 0.5057 & 0.3542 & 0.4592 \\
\hline$l_{w}$ & $\mathrm{~B}(0.5,0.15)$ & 0.4866 & 0.0117 & 0.5033 & 0.0154 & 0.5628 & 0.0159 & 0.4355 & 0.0165 \\
\hline$\xi_{h}$ & $\mathrm{~B}(0.5,0.1)$ & 0.4693 & 0.4628 & 0.3955 & 0.4143 & 0.4382 & 0.3891 & 0.4537 & 0.4575 \\
\hline$\xi_{f}$ & $\mathrm{~B}(0.5,0.1)$ & 0.5168 & 0.4596 & 0.4914 & 0.3758 & 0.4708 & 0.5398 & 0.4496 & 0.5791 \\
\hline$\xi_{w}$ & $\mathrm{~B}(0.5,0.1)$ & 0.5197 & 0.8997 & 0.4955 & 0.9287 & 0.4397 & 0.8929 & 0.4618 & 0.9325 \\
\hline$\lambda_{c}$ & $\mathrm{G}(1,0.2)$ & 0.9009 & 0.9104 & 0.8743 & 1.0532 & 1.0008 & 1.0436 & 0.8002 & 0.8097 \\
\hline$\lambda_{i}$ & $\mathrm{G}(0.25,0.2)$ & 0.2562 & 0.0917 & 0.2015 & 0.1139 & 0.3044 & 0.1216 & 0.1759 & 0.0592 \\
\hline$\rho$ & $\mathrm{N}(0.75,0.1)$ & 0.7542 & 0.6214 & 0.7617 & 0.6798 & 0.7053 & 0.5736 & 0.7328 & 0.5495 \\
\hline$r_{\pi}$ & $\mathrm{N}(1.5,0.25)$ & 1.4877 & 1.2336 & 1.5215 & 1.2581 & 1.6022 & 1.3178 & 1.4582 & 1.4046 \\
\hline$r_{y}$ & $\mathrm{~N}(0.25,0.12)$ & 0.0834 & 0.1682 & 0.1329 & 0.2305 & 0.0697 & 0.1913 & 0.0875 & 0.1477 \\
\hline$r_{\Delta y}$ & $\mathrm{~N}(0.25,0.12)$ & 0.0989 & 0.1047 & 0.1043 & 0.0896 & 0.1434 & 0.0822 & 0.1170 & 0.0751 \\
\hline$\chi_{1}$ & $\mathrm{~B}(0.07,0.02)$ & - & - & - & - & - & - & 0.0631 & 0.0343 \\
\hline$\chi_{2}$ & $\mathrm{~B}(0.07,0.02)$ & - & - & - & - & - & - & 0.0538 & 0.0530 \\
\hline$\chi_{3}$ & $\mathrm{~B}(0.07,0.02)$ & - & - & - & - & - & - & 0.0721 & 0.0573 \\
\hline \multicolumn{10}{|c|}{ Shock persistence } \\
\hline$\rho_{c}$ & $\mathrm{~B}(0.5,0.2)$ & 0.3700 & 0.1068 & 0.4050 & 0.1449 & 0.2869 & 0.1564 & 0.7355 & 0.0940 \\
\hline$\rho_{i}$ & $\mathrm{~B}(0.5,0.2)$ & 0.6689 & 0.9036 & 0.4415 & 0.8471 & 0.5646 & 0.9205 & 0.4052 & 0.9075 \\
\hline$\rho_{g}$ & $\mathrm{~B}(0.5,0.2)$ & 0.4398 & 0.7379 & 0.5891 & 0.7892 & 0.5160 & 0.7694 & 0.4486 & 0.7652 \\
\hline$\rho_{a}$ & $\mathrm{~B}(0.5,0.2)$ & 0.4528 & 0.9677 & 0.5131 & 0.9769 & 0.5107 & 0.9448 & 0.5483 & 0.8546 \\
\hline$\rho_{r}$ & $\mathrm{~B}(0.5,0.2)$ & 0.3577 & 0.3997 & 0.3859 & 0.3191 & 0.5732 & 0.2629 & 0.4091 & 0.1908 \\
\hline$\rho_{h}$ & $\mathrm{~B}(0.5,0.2)$ & 0.5152 & 0.2111 & 0.3946 & 0.2015 & 0.5812 & 0.3337 & 0.6813 & 0.2263 \\
\hline$\rho_{f}$ & $\mathrm{~B}(0.5,0.2)$ & 0.4128 & 0.4859 & 0.4054 & 0.5521 & 0.5350 & 0.4546 & 0.5372 & 0.6639 \\
\hline$\rho_{w}$ & $\mathrm{~B}(0.5,0.2)$ & 0.3281 & 0.2256 & 0.4995 & 0.1198 & 0.4931 & 0.2312 & 0.4589 & 0.2413 \\
\hline$\rho_{k}$ & $\mathrm{~B}(0.5,0.2)$ & 0.9194 & 0.3328 & 0.9589 & 0.3689 & 0.8528 & 0.3848 & 0.9332 & 0.3716 \\
\hline$\rho_{n}$ & $\mathrm{~B}(0.5,0.2)$ & 0.3954 & 0.5128 & 0.5761 & 0.5352 & 0.5649 & 0.5061 & 0.4105 & 0.5186 \\
\hline$\rho_{d}$ & $\mathrm{~B}(0.5,0.2)$ & 0.3747 & - & 0.6010 & - & 0.6184 & - & 0.4063 & - \\
\hline \multicolumn{10}{|c|}{ Shock standard deviations } \\
\hline$\varepsilon_{c}$ & IG $(0.5 \%$, inf $)$ & 0.0120 & 0.0016 & 0.0027 & 0.0014 & 0.0096 & 0.0014 & 0.0072 & 0.0014 \\
\hline$\varepsilon_{i}$ & IG $(0.5 \%$, inf $)$ & 0.0039 & 0.0027 & 0.0025 & 0.0041 & 0.0050 & 0.0027 & 0.0034 & 0.0024 \\
\hline$\varepsilon_{g}$ & IG $(0.5 \%$, inf $)$ & 0.0048 & 0.0028 & 0.0027 & 0.0030 & 0.0028 & 0.0026 & 0.0042 & 0.0030 \\
\hline$\varepsilon_{a}$ & IG (0.5\%, inf) & 0.0021 & 0.0023 & 0.0030 & 0.0024 & 0.0021 & 0.0024 & 0.0023 & 0.0022 \\
\hline$\varepsilon_{r}$ & IG $(0.5 \%$, inf $)$ & 0.0032 & 0.0223 & 0.0027 & 0.0233 & 0.0033 & 0.0299 & 0.0031 & 0.0378 \\
\hline$\varepsilon_{h}$ & IG (0.5\%, inf) & 0.0023 & 0.0592 & 0.0025 & 0.0622 & 0.0052 & 0.0654 & 0.0021 & 0.0618 \\
\hline$\varepsilon_{f}$ & IG (0.5\%, inf) & 0.0025 & 0.0053 & 0.0068 & 0.0020 & 0.0053 & 0.0044 & 0.0032 & 0.0044 \\
\hline$\varepsilon_{w}$ & IG (0.5\%, inf) & 0.0031 & 0.0024 & 0.0028 & 0.0027 & 0.0032 & 0.0026 & 0.0023 & 0.0021 \\
\hline$\varepsilon_{k}$ & IG(0.5\%, inf) & 0.0073 & 0.0029 & 0.0074 & 0.0033 & 0.0162 & 0.0063 & 0.0078 & 0.0026 \\
\hline$\varepsilon_{n}$ & IG $(0.5 \%$, inf $)$ & 0.0020 & 0.0042 & 0.0033 & 0.0033 & 0.0036 & 0.0028 & 0.0024 & 0.0021 \\
\hline$\varepsilon_{d}$ & IG $(0.5 \%$, inf $)$ & 0.0031 & - & 0.0040 & - & 0.0045 & - & 0.0051 & \\
\hline
\end{tabular}

Notes: ${ }^{a}$ The abbreviations used for the prior distributions are: $\mathrm{B}=$ beta, $\mathrm{N}=$ normal, $\mathrm{G}=$ gamma, $\mathrm{IG}=$ inverse gamma. The mean and standard deviations of the prior densities are displayed in parentheses. 
Table 2. Data versus model simulations

\begin{tabular}{|c|c|c|c|c|c|}
\hline & & \multicolumn{4}{|c|}{ Calibrated model moments } \\
\hline & Data & baseline & $\begin{array}{c}\text { financial } \\
\text { correlation } \\
\text { coefficient }=0.5\end{array}$ & $\begin{array}{c}\text { financial } \\
\text { correlation } \\
\text { coefficient = } 1\end{array}$ & $\begin{array}{l}\text { endogenous } \\
\text { correlation }\end{array}$ \\
\hline$\rho\left(y, y^{*}\right)$ & 0.679 & -0.078 & 0.133 & 0.346 & 0.690 \\
\hline$\rho\left(i, i^{*}\right)$ & 0.713 & 0.129 & 0.335 & 0.549 & 0.808 \\
\hline$\rho\left(c, c^{*}\right)$ & 0.508 & -0.265 & -0.217 & -0.169 & 0.130 \\
\hline$\rho\left(l, l^{*}\right)$ & 0.672 & -0.119 & 0.041 & 0.196 & 0.459 \\
\hline$\rho(r k, r k *)$ & 0.406 & 0.093 & 0.404 & 0.801 & 0.741 \\
\hline$\rho\left(n, n^{*}\right)$ & 0.894 & 0.013 & 0.409 & 0.810 & 0.247 \\
\hline$\rho\left(r, r^{*}\right)$ & 0.632 & 0.198 & 0.280 & 0.359 & 0.207 \\
\hline$\rho\left(\pi, \pi^{*}\right)$ & 0.399 & 0.127 & 0.316 & 0.498 & 0.180 \\
\hline$\rho\left(w, w^{*}\right)$ & 0.054 & -0.026 & 0.039 & 0.103 & 0.307 \\
\hline
\end{tabular}

Note: In the baseline model, the standard deviation and the persistence parameter of each shock is set equal to 0.01 and 0.9 respectively. To obtain the results in columns 3 and 4, we set the interest rate, net worth and cost of capital correlation coefficients to equal 0.5 and 1 , respectively. 
Figure 1: US and Euro Area bond yields and growth rates of output and stock market indices
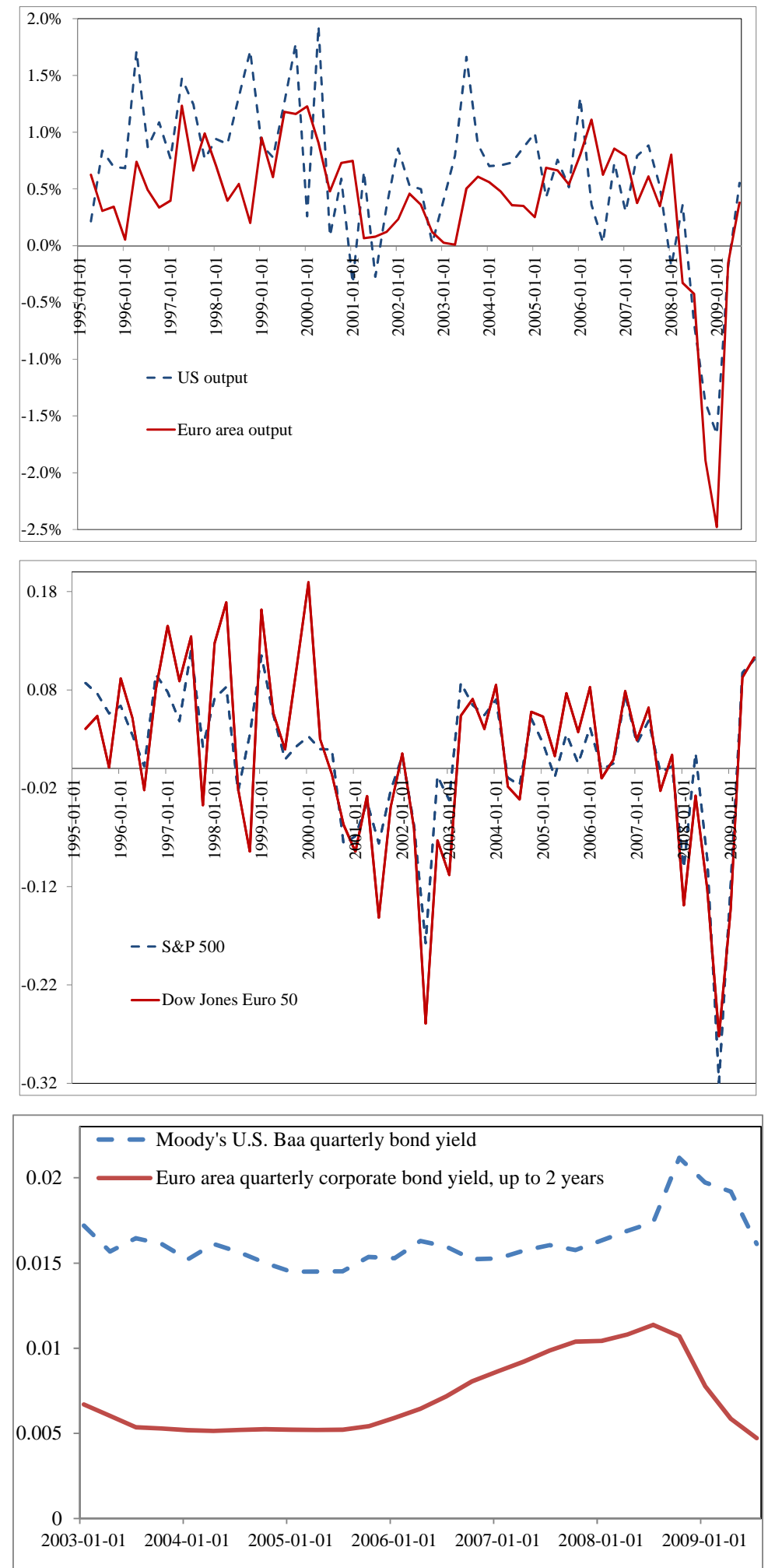

Note: The data definitions are provided in Appendix A. 
Figure 2. Responses to an annualized 100 basis points U.S. interest rate shock (baseline model)
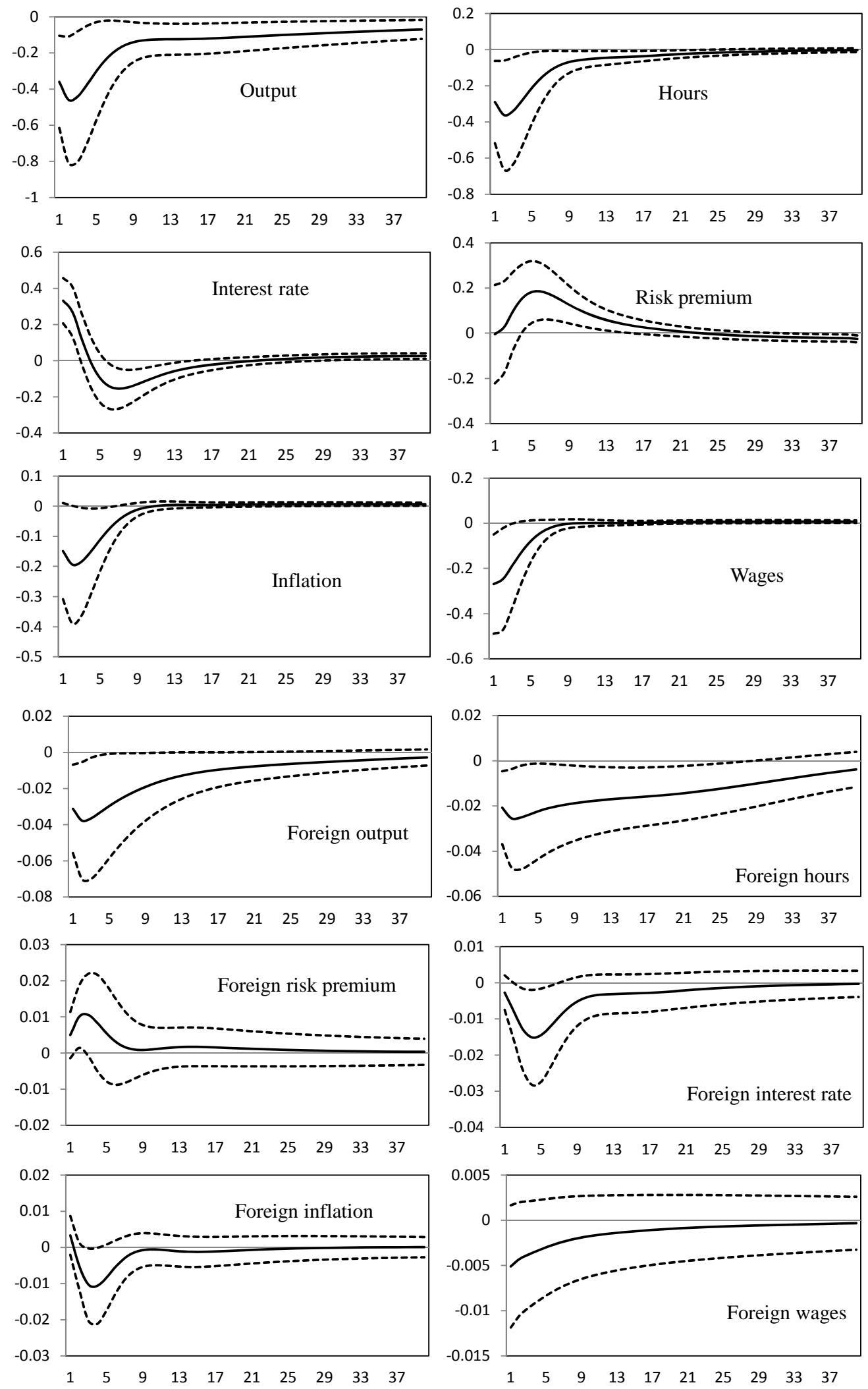

Note: The figures display the mean responses and the 95 percent confidence intervals. 
Figure 3. Responses to an annualized 1 percent U.S. credit supply shock (baseline model)
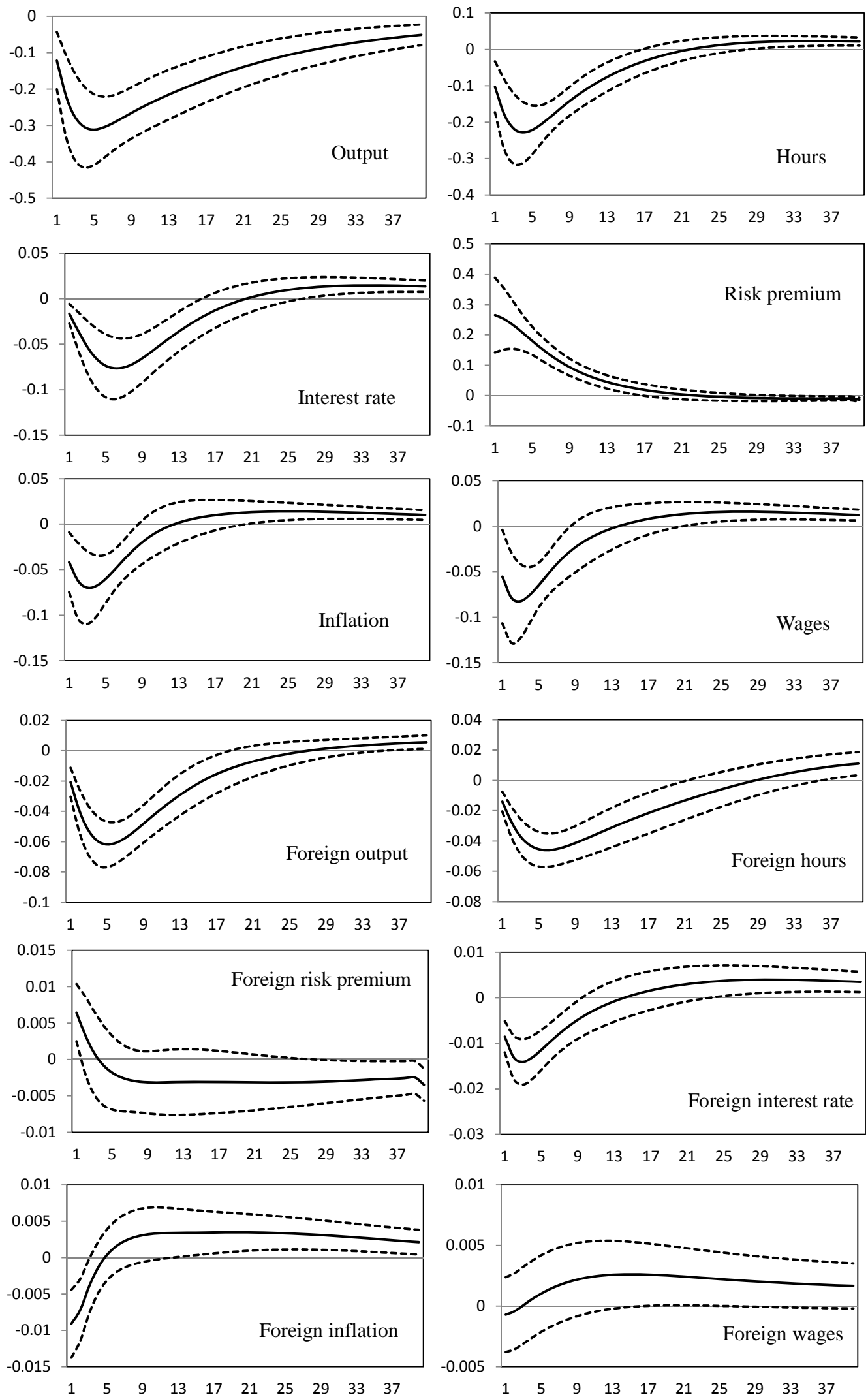

Note: The figures display the mean responses and the $95 \%$ confidence intervals. 
Figure 4. Responses to a 1 percent positive U.S. net worth shock (baseline model)
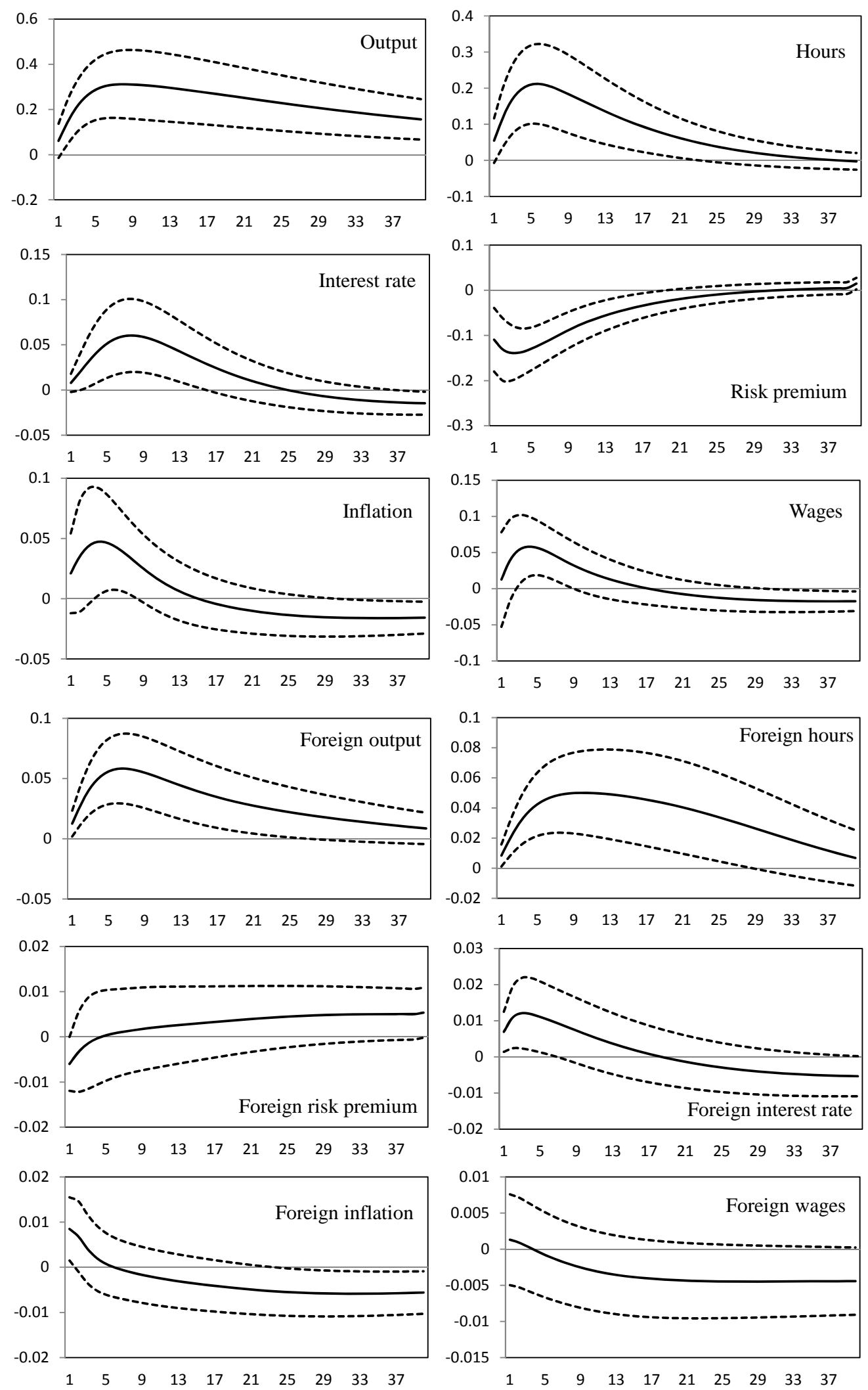

Note: The figures display the mean responses and the 95 percent confidence intervals. 
Figure 5. Baseline responses to other shocks (U.S. output versus Euro Area output responses)
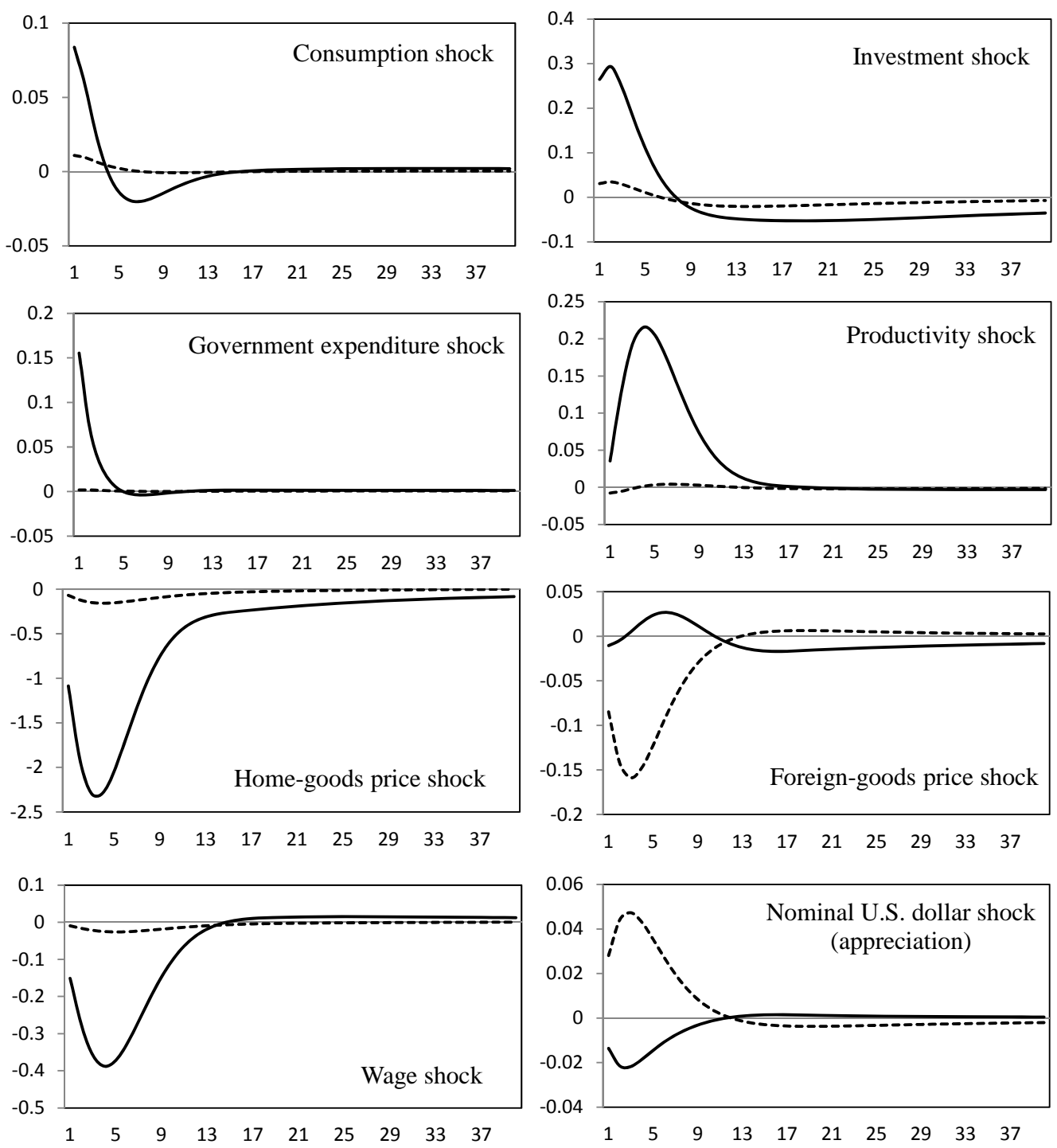

---------- Euro Area output response

\section{U.S. Output response}

Note: the figure displays the mean responses to 1 percent shocks. 
Figure 6. Shock correlation and financial frictions (Annualized 100 basis point U.S. interest rate shock)
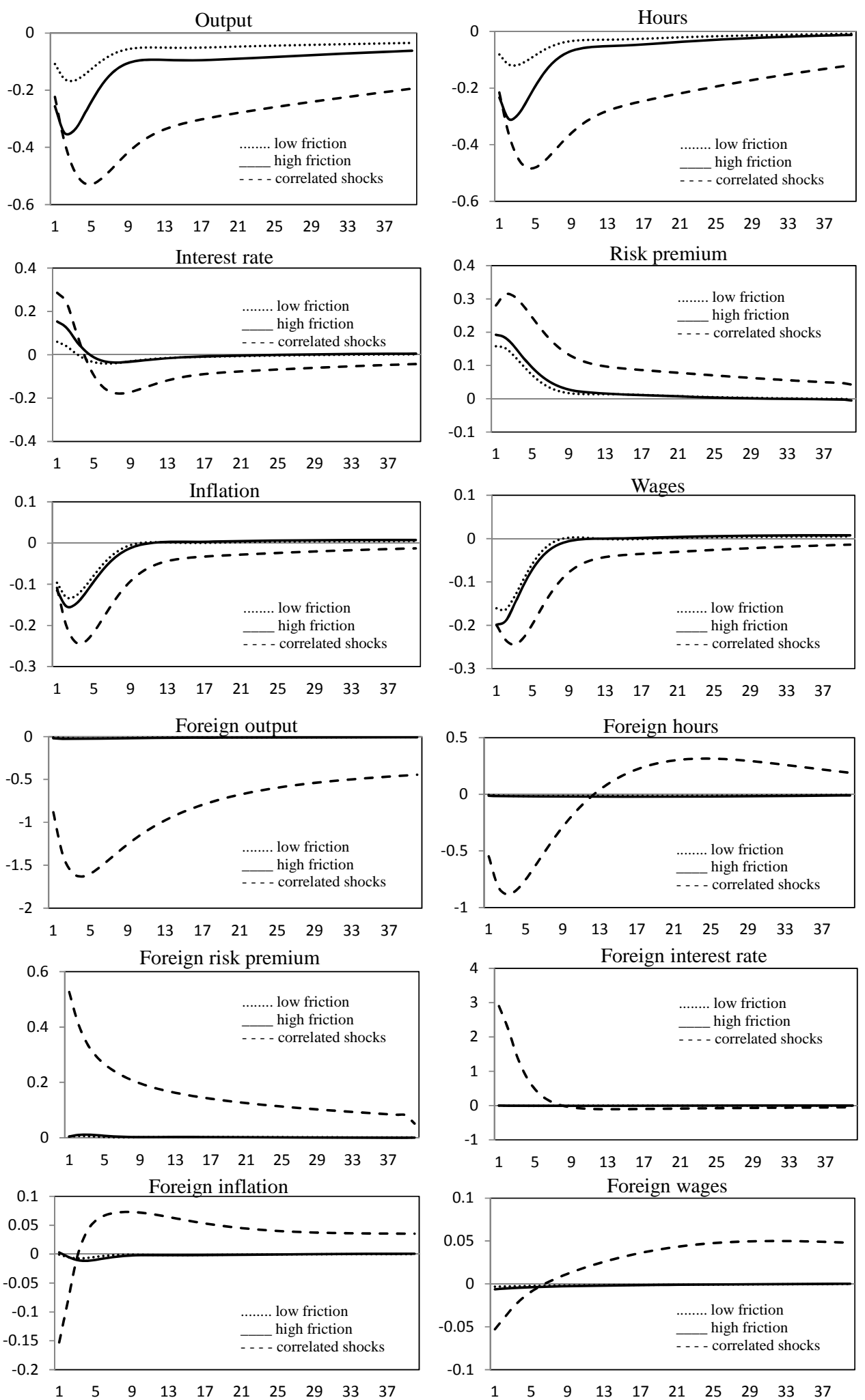

Note: To obtain the impulse responses in the model with low frictions, we set the leverage elasticity parameter $\chi$ to and arbitrarily low value. The estimated values of shock correlations are used to compute the impulse responses from the model with financial correlation. 
Figure 7. Historical decomposition of Euro Area output

\section{Baseline model}

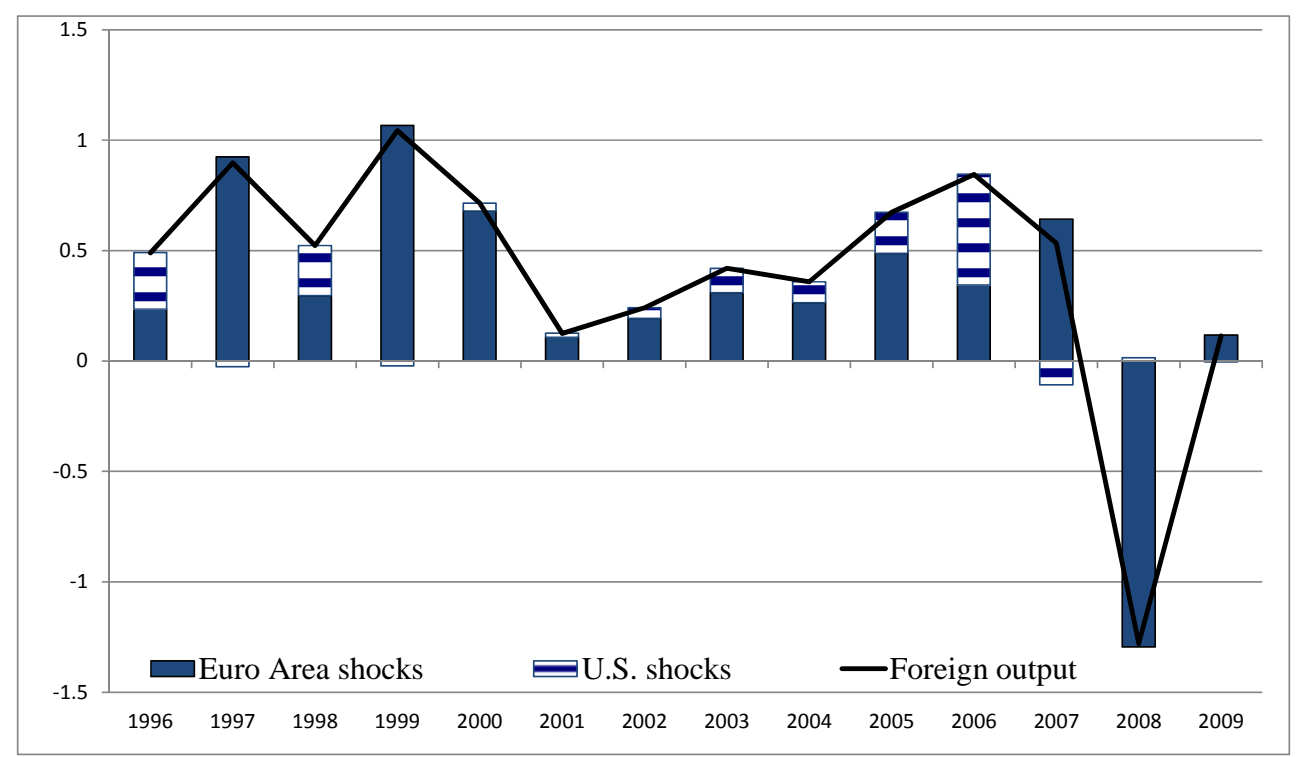

\section{Model with financial correlation}

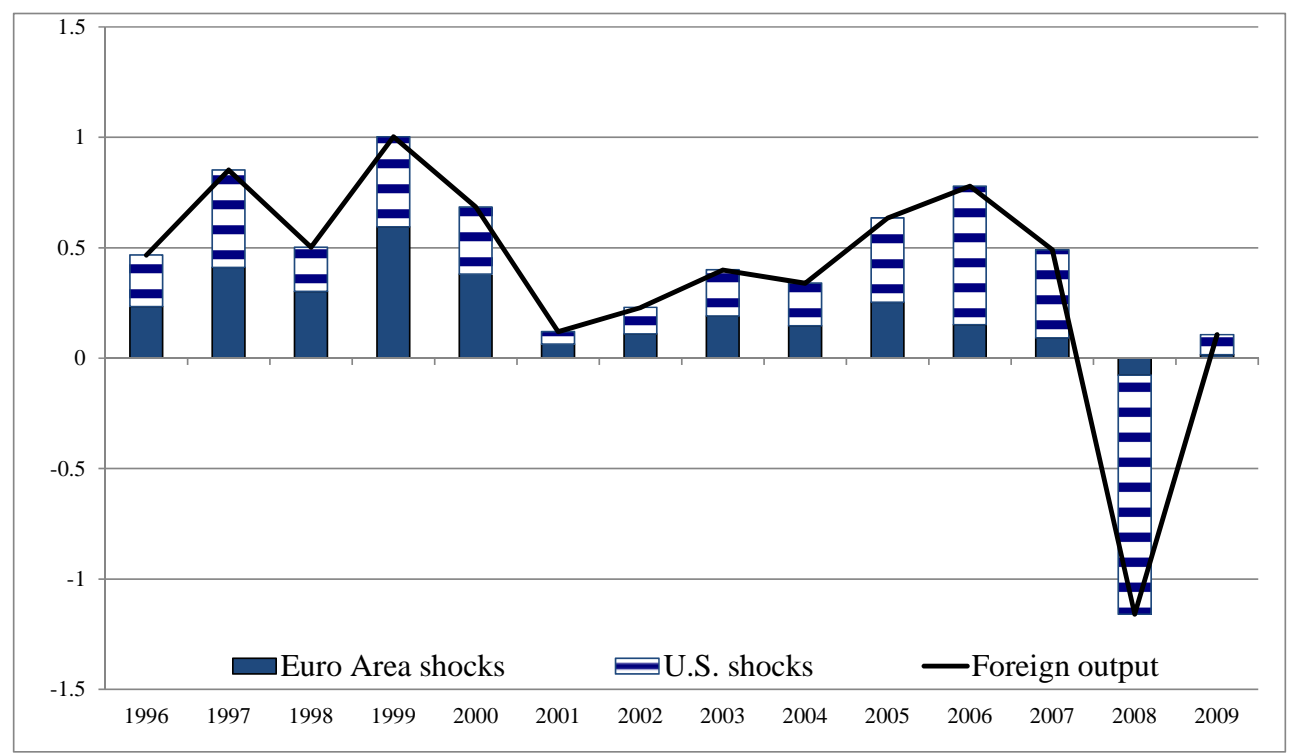

Note: Euro Area and U.S. shocks include consumption, government expenditure, productivity, monetary, homegoods price, imported-goods price, wage, interest rate, cost of capital and net worth shocks. In obtaining the initial share values, we excluded the first year. 
Figure 8. Responses to financial shocks, with cross-regional banking

\section{$\underline{\text { Annualized } 100 \text { basis points U.S. interest rate shock }}$}
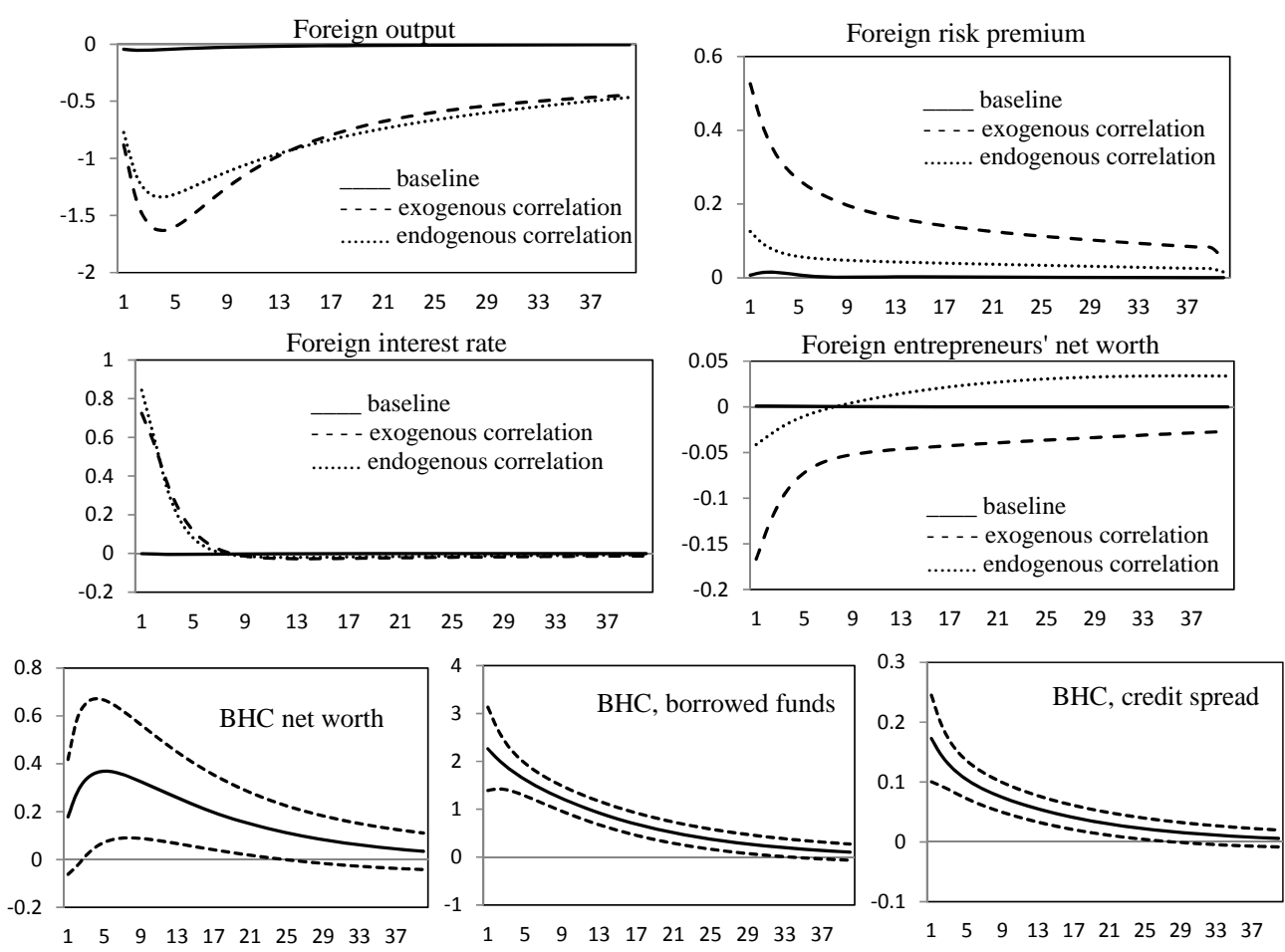

\section{1 percent U.S. net worth shock}
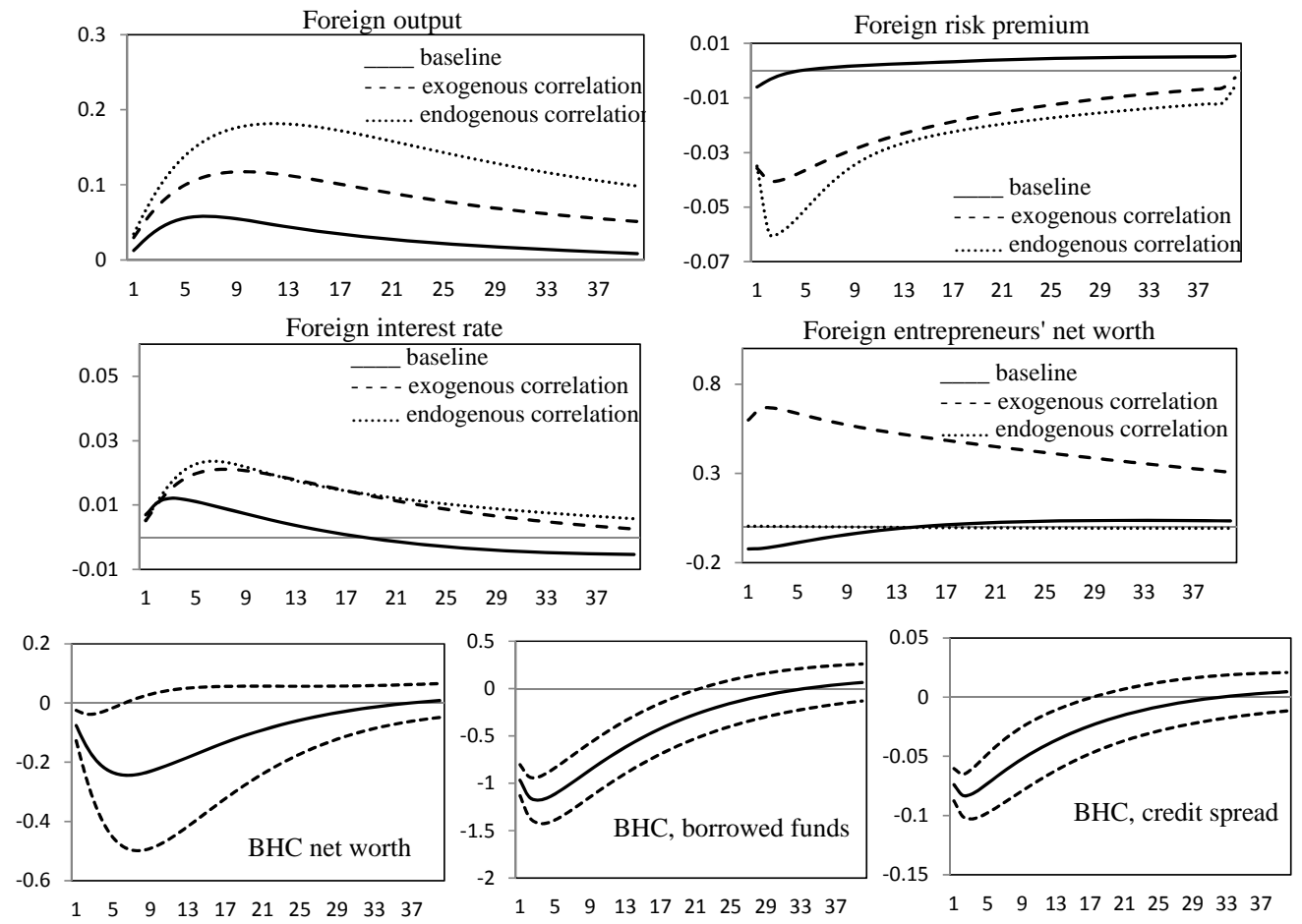

Note: The estimated values of shock correlations are used to compute the impulse responses in the model with financial correlation. In the graphs that display BHC specific variables, the $95 \%$ confidence intervals are included. 
Figure 9. Responses to other shocks, with cross-regional banking (endogenous correlation)

\section{$\underline{\text { Productivity shock }}$}
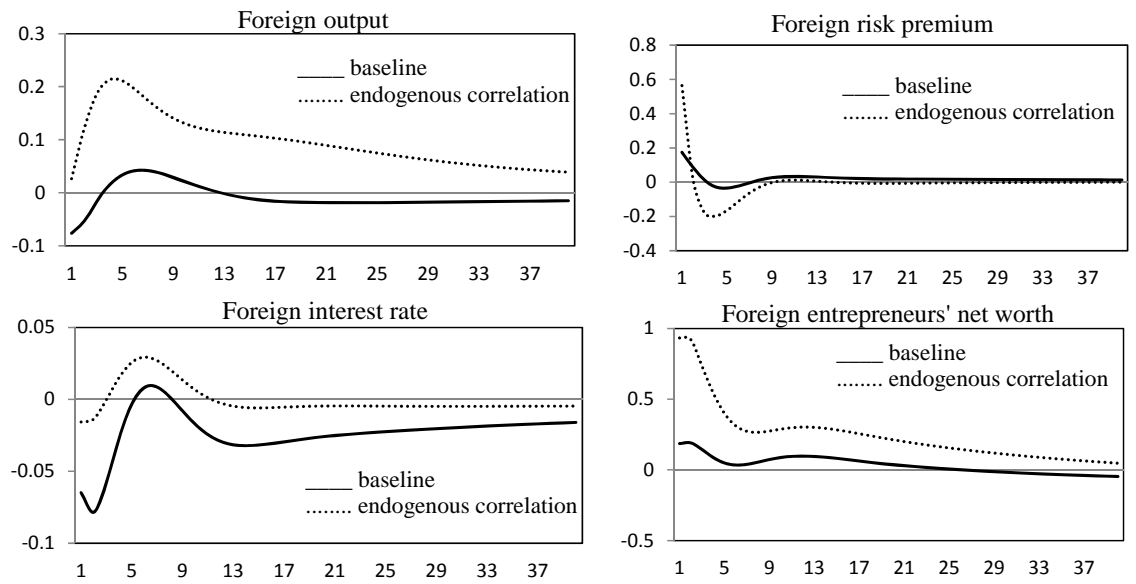

\section{Consumption shock}
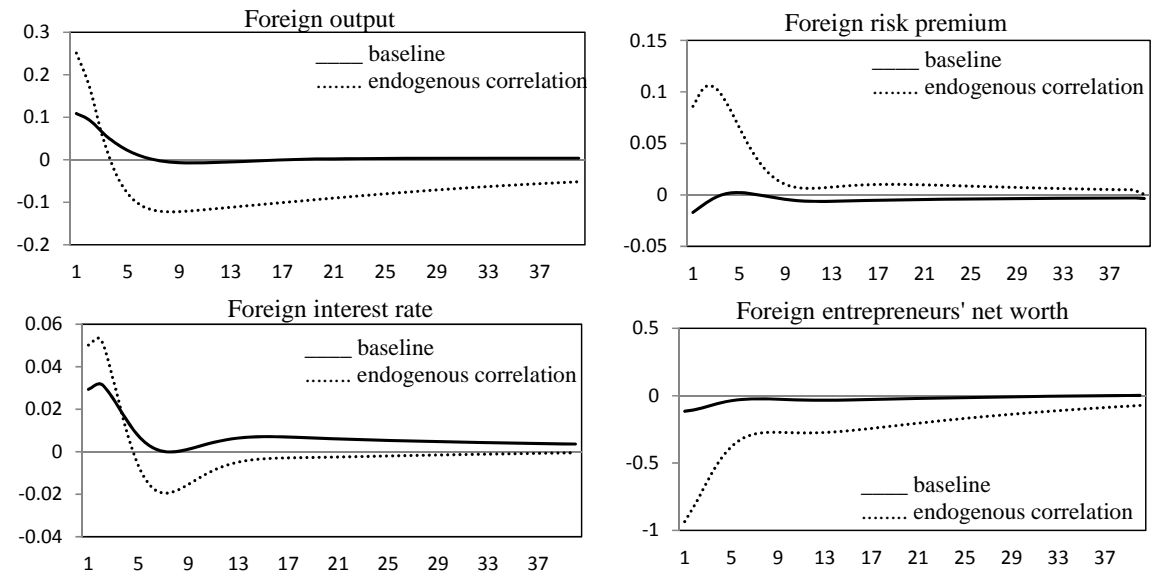

\section{Price shock}
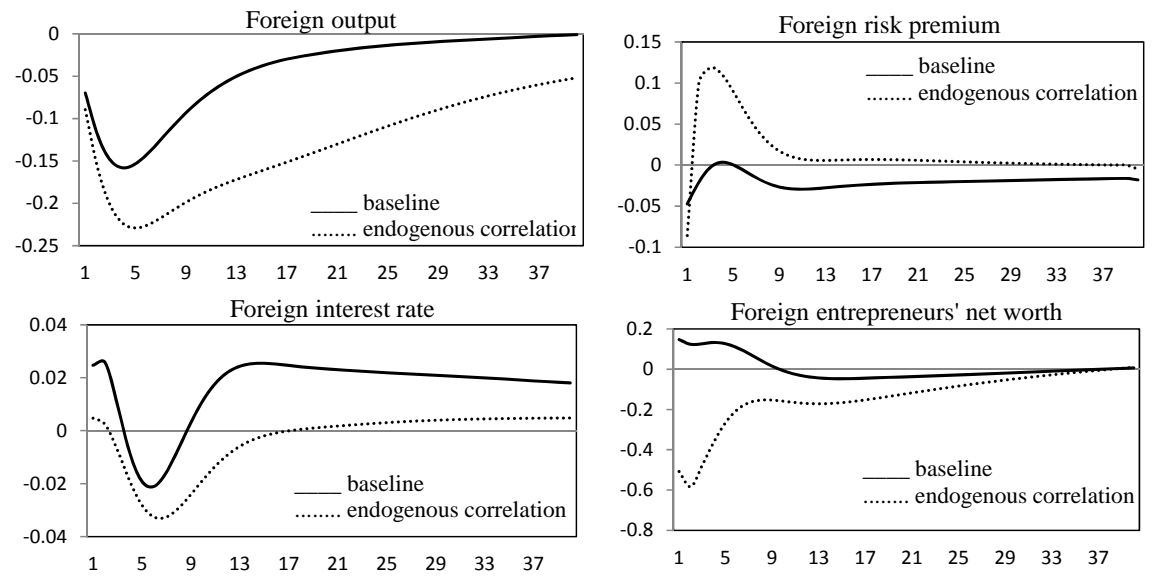

Note: The graphs represent the responses to 1 percent shocks. 